Article

\title{
Preparation and Photocatalytic Performance for Degradation of Rhodamine B of $\mathrm{AgPt} / \mathrm{Bi}_{4} \mathrm{Ti}_{3} \mathrm{O}_{12}$ Composites
}

\author{
Gaoqian Yuan ${ }^{1}$, Gen Zhang ${ }^{1}$, Kezhuo $\mathrm{Li}^{1}{ }^{1}$, Faliang $\mathrm{Li}^{1,2, *}$, Yunbo Cao ${ }^{1}$, Jiangfeng $\mathrm{He}^{1}$, \\ Zhong Huang ${ }^{1}$, Quanli Jia ${ }^{3}{ }^{\circledR}$, Shaowei Zhang ${ }^{4}$ and Haijun Zhang ${ }^{1, * \mathbb{C}}$
}

1 The State Key Laboratory of Refractories and Metallurgy, Wuhan University of Science and Technology, Wuhan 430081, China; yuangaoqian@126.com (G.Y.); zhang0812m@163.com (G.Z.); likezhuo0206@126.com (K.L.); 15623242376@163.com (Y.C.); hejiangfeng823102@163.com (J.H.); huangzhong@wust.edu.cn (Z.H.)

2 Jiangxi Engineering Research Center of Industrial Ceramics, Pingxiang 337022, China

3 Henan Key Laboratory of High Temperature Functional Ceramics, Zhengzhou University, 75 Daxue Road, Zhengzhou 450052, China; jiaquanli@zzu.edu.cn

4 College of Engineering, Mathematics and Physical Sciences, University of Exeter, Exeter EX4 4QF, UK; s.zhang@exeter.ac.uk

* Correspondence: lfliang@wust.edu.cn (F.L.); zhanghaijun@wust.edu.cn (H.Z.); Tel.: +86-133-6727-5129 (F.L.); +86-27-6886-2829 (H.Z)

Received: 13 October 2020; Accepted: 3 November 2020; Published: 5 November 2020

\begin{abstract}
Loading a noble metal on $\mathrm{Bi}_{4} \mathrm{Ti}_{3} \mathrm{O}_{12}$ could enable the formation of the Schottky barrier at the interface between the former and the latter, which causes electrons to be trapped and inhibits the recombination of photoelectrons and photoholes. In this paper, $\mathrm{AgPt} / \mathrm{Bi}_{4} \mathrm{Ti}_{3} \mathrm{O}_{12}$ composite photocatalysts were prepared using the photoreduction method, and the effects of the type and content of noble metal on the photocatalytic performance of the catalysts were investigated. The photocatalytic degradation of rhodamine B (RhB) showed that the loading of AgPt bimetallic nanoparticles significantly improved the catalytic performance of $\mathrm{Bi}_{4} \mathrm{Ti}_{3} \mathrm{O}_{12}$. When $0.10 \mathrm{wt} \%$ noble metal was loaded, the degradation rate for $\mathrm{RhB}$ of $\mathrm{Ag}_{0.7} \mathrm{Pt}_{0.3} / \mathrm{Bi}_{4} \mathrm{Ti}_{3} \mathrm{O}_{12}$ was $0.027 \mathrm{~min}^{-1}$, which was respectively about 2, 1.7 and 3.7 times as that of $\mathrm{Ag} / \mathrm{Bi}_{4} \mathrm{Ti}_{3} \mathrm{O}_{12}, \mathrm{Pt}_{/} / \mathrm{Bi}_{3} \mathrm{Ti}_{4} \mathrm{O}_{12}$ and $\mathrm{Bi}_{4} \mathrm{Ti}_{3} \mathrm{O}_{12}$. The reasons may be attributed as follows: (i) the utilization of visible light was enhanced due to the surface plasmon resonance effect of $\mathrm{Ag}$ and $\mathrm{Pt}$ in the visible region; (ii) Ag nanoparticles mainly acted as electron acceptors to restrain the recombination of photogenerated electron-hole pairs under visible light irradiation; and (iii) $\mathrm{Pt}$ nanoparticles acted as electron cocatalysts to further suppress the recombination of photogenerated electron-hole pairs. The photocatalytic performance of $\mathrm{Ag}_{0.7} \mathrm{Pt}_{0.3} / \mathrm{Bi}_{4} \mathrm{Ti}_{3} \mathrm{O}_{12}$ was superior to that of $\mathrm{Ag} / \mathrm{Bi}_{4} \mathrm{Ti}_{3} \mathrm{O}_{12}$ and $\mathrm{Pt} / \mathrm{Bi}_{3} \mathrm{Ti}_{4} \mathrm{O}_{12}$ owing to the synergistic effect between $\mathrm{Ag}$ and $\mathrm{Pt}$ nanoparticles.
\end{abstract}

Keywords: photocatalytic; Rhodamine B; photoreduction; $\mathrm{Bi}_{4} \mathrm{Ti}_{3} \mathrm{O}_{12} ; \mathrm{AgPt} / \mathrm{Bi}_{4} \mathrm{Ti}_{3} \mathrm{O}_{12}$

\section{Introduction}

The rapid growth of the chemical industry has led to a large volume of organic dye wastewater. Most of the organic pollutants have carcinogenic effects, posing a huge threat to organisms and human health [1-3]. Therefore, organic pollutants must be detoxified before they enter aquatic ecosystems. Some traditional wastewater treatment processes, such as physical adsorption, chemical oxidation and microbial treatment [4-6], have been proposed to deal with organic dyestuff sewage. However, these methods have suffered from several shortcomings including low efficiency, secondary pollution, and mild degree of harmlessness of pollutant [7-9]. Photocatalysis technology, which can non-selectively 
oxidize and degrade all kinds of organic matter with the ability of deep oxidation, is considered as an acceptable process for the treatment of organic contaminants since only water and non-toxic inorganic substances are produced. In the process of photocatalysis, photocatalysts are always required for achieving excellent catalytic effect. However, for the most widely used semiconductor photocatalysts (such as $\mathrm{TiO}_{2}$ [10], $\mathrm{SrTiO}_{3}$ [11], $\mathrm{ZnS}$ [12] and $\mathrm{ZnO}$ [13]), the utilization of solar energy is usually very low since their bandgap width $E_{\mathrm{g}}$ is always larger than $3.0 \mathrm{eV}$ and can only just absorb ultraviolet light (only $4 \%$ of the total sunlight). Thus, how to improve the usage of solar energy in the photocatalytic removal of organic pollutants has become an important issue.

$\mathrm{Bi}_{4} \mathrm{Ti}_{3} \mathrm{O}_{12}$ can respond to visible light since its bandgap is about $2.9 \mathrm{eV}$, and shows strong photocatalytic activity for the removal of organic pollutants [14-16]. However, the usage of $\mathrm{Bi}_{4} \mathrm{Ti}_{3} \mathrm{O}_{12}$ is still limited because the photon efficiency is low and the photogenerated electrons and holes are easy to recombine. Noble metal nanoparticles (NPs) can be used as the accumulation ground of photogenerated electrons to facilitate the catalytic reactions involving electrons, and thus are widely employed as modifiers to enhance the photocatalytic performance of semiconductors [17-19]. When precious metals and semiconductors contact together, electrons on the surface of the latter will migrate to the surface of the former until their Fermi energy levels equalize. Since charges on the metal surface and holes on the semiconductor surface are both excessive, a Schottky barrier can be formed on the metal-semiconductor interface. As a result, the separation of photogenerated electrons and holes is promoted, and an improved photocatalytic performance is obtained [20-22].

In the present paper, $\mathrm{Bi}_{4} \mathrm{Ti}_{3} \mathrm{O}_{12}$ nanosheets were firstly prepared by a molten salt method, and then $\mathrm{AgPt}$ bimetallic NPs were assembled on the prepared $\mathrm{Bi}_{4} \mathrm{Ti}_{3} \mathrm{O}_{12}$ nanosheets via an in situ photoreduction method to prepare $\mathrm{AgPt} / \mathrm{Bi}_{4} \mathrm{Ti}_{3} \mathrm{O}_{12}$ composites, finally the photocatalytic performance of as-prepared $\mathrm{AgPt} / \mathrm{Bi}_{4} \mathrm{Ti}_{3} \mathrm{O}_{12}$ composites on the degradation of rhodamine $\mathrm{B}(\mathrm{RhB})$ under visible light was investigated. As far as we know, there has been no study on the decoration of AgPt bimetallic NPs on $\mathrm{Bi}_{4} \mathrm{Ti}_{3} \mathrm{O}_{12}$ photocatalyst.

\section{Materials and Methods}

\subsection{Materials}

Titanium oxide $\left(\mathrm{TiO}_{2}\right)$ and bismuth oxide $\left(\mathrm{Bi}_{2} \mathrm{O}_{3}\right)$ were purchased from Shanghai Makclin Biochemical Co., Ltd. (Shanghai, China). Silver nitrate $\left(\mathrm{AgNO}_{3}\right)$ was purchased from Tianjin Kaitong Chemical Reagent Co., Ltd. (Tianjin, China). Chloroplatinic acid hexahydrate $\left(\mathrm{H}_{2} \mathrm{PtCl}_{6} \cdot 6 \mathrm{H}_{2} \mathrm{O}\right)$ was purchased from Shanghai Aladdin Bio-chem Technology Co., Ltd. (Shanghai, China). Potassium chloride $(\mathrm{KCl})$ and sodium chloride $(\mathrm{NaCl})$ were purchased from Tianjin Bodi Chemical Reagent Co., Ltd. (Tianjin, China) All chemicals were used as purchased without further purification.

\subsection{Preparation of $\mathrm{Bi}_{4} \mathrm{Ti}_{3} \mathrm{O}_{12}$ Powders}

Preparation of $\mathrm{Bi}_{4} \mathrm{Ti}_{3} \mathrm{O}_{12}$ powders via the molten salt method was similar to our previously published paper [23-27]. Typically, stoichiometric amounts of $\mathrm{Bi}_{2} \mathrm{O}_{3}, \mathrm{TiO}_{2}, \mathrm{NaCl}$ and $\mathrm{KCl}$ were weighed firstly according to a predetermined ratio shown in Table 1 . After that, the raw materials and molten salt medium were mixed in a planetary ball mill for $3 \mathrm{~h}$ under a rotating speed of $300 \mathrm{r} / \mathrm{min}$ with ethanol as milling medium. Subsequently, the mixed powders were dried and then subjected to $2 \mathrm{~h}$ heating treatment at 700,800 and $900{ }^{\circ} \mathrm{C}$ in a muffle furnace. Finally, $\mathrm{Bi}_{4} \mathrm{Ti}_{3} \mathrm{O}_{12}$ powders were obtained after washing, filtration and drying, and the samples were labeled as $\mathrm{Bi}_{4} \mathrm{Ti}_{3} \mathrm{O}_{12}-\mathrm{T}-\mathrm{M}$ ( $\mathrm{T}$ is the heat treatment temperature, $\mathrm{M}$ is the mass ratio of molten salt medium and raw material).

\subsection{Assembly of $\mathrm{Ag}$ and Pt Nanoparticles (NPs) on $\mathrm{Bi}_{4} \mathrm{Ti}_{3} \mathrm{O}_{12}$ Nanosheets}

$\mathrm{Ag} / \mathrm{Bi}_{4} \mathrm{Ti}_{3} \mathrm{O}_{12}, \mathrm{Pt} / \mathrm{Bi}_{4} \mathrm{Ti}_{3} \mathrm{O}_{12}$ and $\mathrm{AgPt} / \mathrm{Bi}_{4} \mathrm{Ti}_{3} \mathrm{O}_{12}$ were prepared by a photoreduction method. The whole preparation procedure involved four steps as follows: (i) $1 \mathrm{~g}$ as-prepared $\mathrm{Bi}_{4} \mathrm{Ti}_{3} \mathrm{O}_{12}$ powders were dispersed in $200 \mathrm{~mL}$ deionized water; (ii) $0.1 \mathrm{~mol} / \mathrm{L} \mathrm{AgNO}_{3}$ solution, $7.72 \mathrm{mmol} / \mathrm{L} \mathrm{H}_{2} \mathrm{PtCl}_{6} \cdot 6 \mathrm{H}_{2} \mathrm{O}$ 
solution and the mixed solution of $\mathrm{AgNO}_{3}$ and $\mathrm{H}_{2} \mathrm{PtCl}_{6} \cdot 6 \mathrm{H}_{2} \mathrm{O}$ was separately added to the as-prepared $\mathrm{Bi}_{4} \mathrm{Ti}_{3} \mathrm{O}_{12}$ suspension with the predetermined proportions shown in Table 2; (iii) The as-prepared suspensions were irradiated under a $300 \mathrm{~W}$ xenon lamp for $60 \mathrm{~min}$ (a $400 \mathrm{~nm}$ filter was used to block ultraviolet (UV) light $(\lambda<400 \mathrm{~nm})$ ). In this process, $\mathrm{Ag}^{+}$and $\mathrm{Pt}^{4+}$ was respectively reduced to $\mathrm{Ag}$ NPs and Pt NPs; and iv) The $\mathrm{Ag} / \mathrm{Bi}_{4} \mathrm{Ti}_{3} \mathrm{O}_{12}, \mathrm{Pt} / \mathrm{Bi}_{4} \mathrm{Ti}_{3} \mathrm{O}_{12}$ and $\mathrm{AgPt} / \mathrm{Bi}_{4} \mathrm{Ti}_{3} \mathrm{O}_{12}$ powders were obtained after the mixture was filtered, washed and dried (drying conditions: $80{ }^{\circ} \mathrm{C}$ for $12 \mathrm{~h}$ in an electric drying oven).

Table 1. Synthesis conditions and batch of $\mathrm{Bi}_{4} \mathrm{Ti}_{3} \mathrm{O}_{12}$.

\begin{tabular}{|c|c|c|}
\hline $\begin{array}{l}\text { Firing } \\
\text { Conditions }\end{array}$ & $\begin{array}{l}\text { Salt Medium Composition } \\
\text { (Molar Ratio) }\end{array}$ & Mass Ratio of Salt to Reactant \\
\hline $700{ }^{\circ} \mathrm{C} / 2 \mathrm{~h}$ & \multirow{3}{*}{$\mathrm{NaCl}: \mathrm{KCl}(1: 1)$} & \multirow{3}{*}{$1: 1$} \\
\hline $800{ }^{\circ} \mathrm{C} / 2 \mathrm{~h}$ & & \\
\hline $900^{\circ} \mathrm{C} / 2 \mathrm{~h}$ & & \\
\hline $700{ }^{\circ} \mathrm{C} / 2 \mathrm{~h}$ & \multirow{3}{*}{$\mathrm{NaCl}: \mathrm{KCl}(1: 1)$} & \multirow{3}{*}{$2: 1$} \\
\hline $800^{\circ} \mathrm{C} / 2 \mathrm{~h}$ & & \\
\hline $900{ }^{\circ} \mathrm{C} / 2 \mathrm{~h}$ & & \\
\hline $700^{\circ} \mathrm{C} / 2 \mathrm{~h}$ & \multirow{3}{*}{$\mathrm{NaCl}: \mathrm{KCl}(1: 1)$} & \multirow{3}{*}{$3: 1$} \\
\hline $800{ }^{\circ} \mathrm{C} / 2 \mathrm{~h}$ & & \\
\hline $900{ }^{\circ} \mathrm{C} / 2 \mathrm{~h}$ & & \\
\hline
\end{tabular}

Table 2. Batch compositions of $\mathrm{Ag} / \mathrm{Bi}_{4} \mathrm{Ti}_{3} \mathrm{O}_{12}, \mathrm{Pt} / \mathrm{Bi}_{4} \mathrm{Ti}_{3} \mathrm{O}_{12}$ and $\mathrm{AgPt} / \mathrm{Bi}_{4} \mathrm{Ti}_{3} \mathrm{O}_{12}$ photocatalysts.

\begin{tabular}{|c|c|c|}
\hline $\begin{array}{l}\text { Metal Composition } \\
\text { (Mass Ratio) }\end{array}$ & Loading Capacity & Illumination Condition \\
\hline \multirow{6}{*}{$\mathrm{Ag}$} & $0.1 \mathrm{wt} \%$ & \multirow{12}{*}{$\begin{array}{c}300 \mathrm{~W} \text { xenon lamp } \\
(\lambda>400 \mathrm{~nm}) \\
60 \mathrm{~min}\end{array}$} \\
\hline & $0.2 \mathrm{wt} \%$ & \\
\hline & $0.5 \mathrm{wt} \%$ & \\
\hline & $1.0 \mathrm{wt} \%$ & \\
\hline & $3.0 \mathrm{wt} \%$ & \\
\hline & $5.0 \mathrm{wt} \%$ & \\
\hline $\mathrm{Pt}$ & $0.1 \mathrm{wt} \%$ & \\
\hline Ag:Pt (1:1) & \multirow{5}{*}{$0.1 \mathrm{wt} \%$} & \\
\hline Ag:Pt (7:3) & & \\
\hline Ag:Pt (3:7) & & \\
\hline Ag:Pt (9:1) & & \\
\hline Ag:Pt (1:9) & & \\
\hline
\end{tabular}

\subsection{Characterization}

X-ray diffraction (XRD) was performed on MiniFlex 600 with $\mathrm{Cu} K \alpha$ radiation $(\lambda=1.54178 \AA)$ to investigate the crystal structure of the as-prepared powders. The field-emission scanning electron microscopy (FE-SEM) images, transmission electron microscopy (TEM) images, selected area electron diffraction (SAED) images and energy dispersive spectroscopy (EDS) elemental mapping images were respectively taken on a JEOL JSM-6700F SEM and JEM-2100 HR TEM to observe the microstructure of the as-prepared catalysts. Fourier transform infrared (FT-IR) spectra ranged from $3000-450 \mathrm{~cm}^{-1}$ were recorded on a Nicolet iS50 spectrometer in air at room temperature to differentiate the functional groups formed on the surface of as-prepared catalysts. Chemical composition of as-prepared catalysts 
was analyzed by the inductively coupled plasma mass spectroscopy (ICP-MS, Spectro Flame, Spectro Analytical Instrument, Kleve, Germany). X-ray photoelectron spectroscopy (XPS) measurements were performed using an AMICUS ESCA 3400 XPS with Al K $\alpha$ radiation. In order to investigate the elemental information ( $\mathrm{Bi}, \mathrm{Ti}, \mathrm{O}, \mathrm{Ag}$ and $\mathrm{Pt}$ ), all XPS spectra were calibrated by shifting the detected adventitious carbon C 1s peak to $284.8 \mathrm{eV}$. A RF-6000 fluorescence spectrophotometer was used to measure the photoluminescence (PL) spectra of the samples (excitation wavelength: $320 \mathrm{~nm}$ ). Ultraviolet-visible (UV-Vis) absorption spectra were recorded using a UV-Vis spectrophotometer (Shimadzu UV-3600, Kyoto, Japan) to study the responsive behavior under UV and visible light irradiation of the as-prepared catalysts.

\subsection{Photocatalytic Activity}

RhB aqueous solution was chosen to simulate wastewater and the variation of its concentration under the irradiation of xenon lamp $(\lambda>400 \mathrm{~nm})$ was measured at $\lambda=554 \mathrm{~nm}$ by a UV-Vis spectrophotometer. Four steps were performed to investigate the performance of the as-prepared catalysts: (i) $3.2 \mathrm{mg} / \mathrm{L} \mathrm{RhB}$ solution was prepared firstly and then its absorption spectrum was determined by a UV-Vis spectrophotometer; (ii) $200 \mathrm{mg}$ as-prepared photocatalysts were put into $200 \mathrm{~mL}$ RhB solution with an initial concentration of $3.2 \mathrm{mg} / \mathrm{L}$, and then, in order to achieve adsorption-desorption equilibrium, the obtained mixture was stirred in the dark for $1 \mathrm{~h}$. After that, $3 \mathrm{~mL}$ solution was taken out to be centrifuged and the supernatant was taken out for absorption spectrum measurement, from which the adsorbed amount of RhB can be calculated; (iii) The residual mixture was exposed to a xenon lamp irradiation $(\lambda>400 \mathrm{~nm})$ for $30 \mathrm{~min}$ and then $3 \mathrm{~mL}$ solution was taken out to be centrifuged, and the supernatant was taken out to measure its absorption spectrum; and (iv) Step 3 was repeated until the identified absorption spectra were almost unchanged. In order to eliminate the influence of temperature on the photocatalytic behavior, the whole experimental process was carried out in a cooling cycle device.

\subsection{Detection of Reactive Species}

In a typical reactive species trapping experiment, three reactions were carried out to distinguish the reactive species of hole $\left(\mathrm{h}^{+}\right)$, hydroxy radical $(\bullet \mathrm{OH})$ and superoxide radical $\left(\bullet \mathrm{O}^{2-}\right)$ for the photocatalytic degradation process. At first, $200 \mathrm{~mL} \mathrm{RhB}$ solution and $0.2 \mathrm{~g}$ as-prepared catalyst were respectively mixed with $20 \mathrm{~mL}$ ethanol (EtOH), $0.2 \mathrm{mmol}$ benzoquinone (BQ) and $2 \mathrm{mmol}$ triethanolamine (TEOA). Then the mixtures were stirred for $1 \mathrm{~h}$ in dark for achieving adsorption-desorption equilibrium. Finally, the catalytic process as described in Section 2.5 was carried out.

\section{Results}

Figure 1 showed the XRD patterns of $\mathrm{Bi}_{4} \mathrm{Ti}_{3} \mathrm{O}_{12}$ powders $\left(\mathrm{Bi}_{4} \mathrm{Ti}_{3} \mathrm{O}_{12}-800-1\right)$ prepared by molten salt method and $(\mathrm{AgPt})_{0.001} / \mathrm{Bi}_{4} \mathrm{Ti}_{3} \mathrm{O}_{12}$ composites prepared by a photoreduction method. It can be clearly seen that the diffraction peaks of the as-prepared $\mathrm{Bi}_{4} \mathrm{Ti}_{3} \mathrm{O}_{12}$ matched well with the standard card JCPDS-01-080-2143, indicating the crystallinity of synthesized $\mathrm{Bi}_{4} \mathrm{Ti}_{3} \mathrm{O}_{12}$ was high. The diffraction peaks of $\mathrm{Ag}$ and Pt NPs were not observed, and the reason may be ascribed to the low amount of loaded AgPt bimetallic NPs (0.1 wt \%).

Figure 2 presents the SEM images of as-prepared $\mathrm{Bi}_{4} \mathrm{Ti}_{3} \mathrm{O}_{12}$ and $(\mathrm{AgPt})_{0.001} / \mathrm{Bi}_{4} \mathrm{Ti}_{3} \mathrm{O}_{12}$ composite photocatalysts prepared by the photoreduction method. It revealed that all the samples showed a lamellar structure with a grain size of 1-5 $\mu \mathrm{m}$, and that Ag and Pt NPs were too small to be observed in the SEM images. 


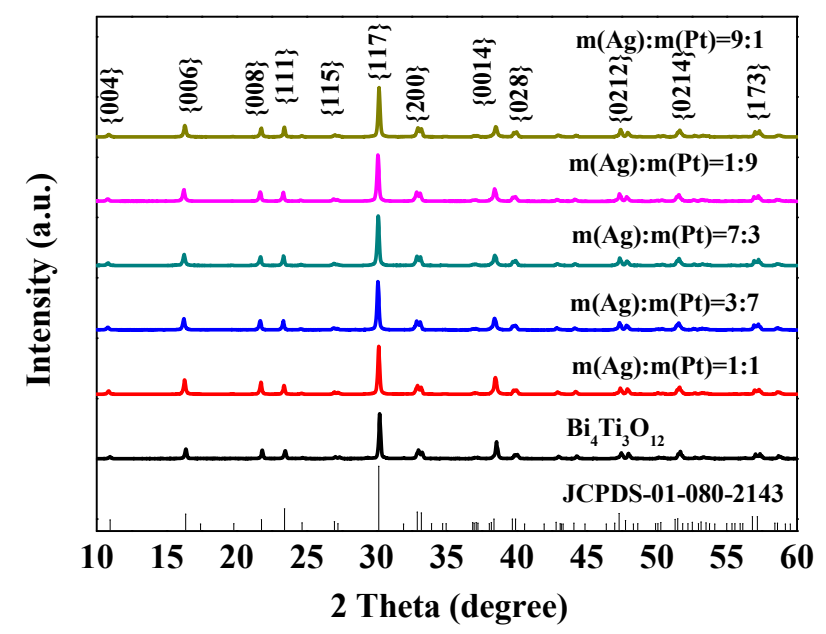

Figure 1. X-ray diffraction (XRD) patterns of $\mathrm{Bi}_{4} \mathrm{Ti}_{3} \mathrm{O}_{12}$ and $(\mathrm{AgPt})_{0.001} / \mathrm{Bi}_{4} \mathrm{Ti}_{3} \mathrm{O}_{12}$ composite photocatalysts prepared by photoreduction method.
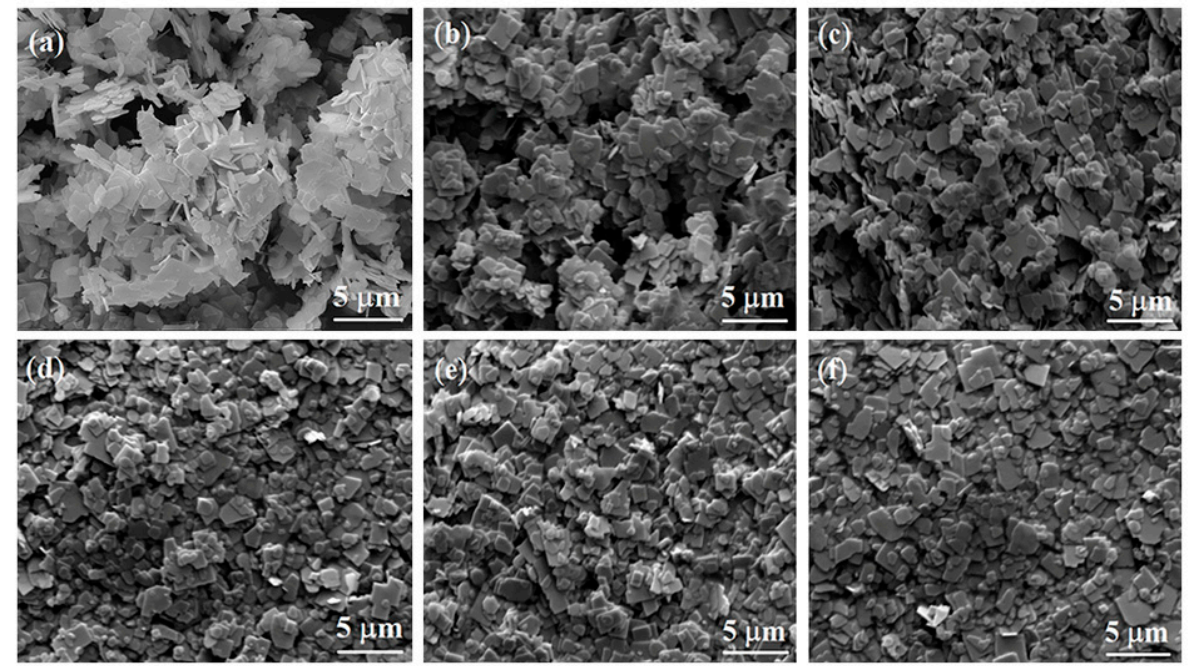

Figure 2. Scanning electron microscopy (SEM) images of pristine $\mathrm{Bi}_{4} \mathrm{Ti}_{3} \mathrm{O}_{12}$ and $(\mathrm{AgPt})_{0.001} / \mathrm{Bi}_{4} \mathrm{Ti}_{3} \mathrm{O}_{12}$ composite photocatalysts prepared by photoreduction method: (a) $\mathrm{Bi}_{4} \mathrm{Ti}_{3} \mathrm{O}_{12} ;(\mathbf{b}) \mathrm{m}(\mathrm{Ag}): \mathrm{m}(\mathrm{Pt})=1: 1$; (c) $\mathrm{m}(\mathrm{Ag}): \mathrm{m}(\mathrm{Pt})=7: 3 ;(\mathbf{d}) \mathrm{m}(\mathrm{Ag}): \mathrm{m}(\mathrm{Pt})=3: 7 ;(\mathbf{e}) \mathrm{m}(\mathrm{Ag}): \mathrm{m}(\mathrm{Pt})=9: 1$ and $(\mathbf{f}) \mathrm{m}(\mathrm{Ag}): \mathrm{m}(\mathrm{Pt})=1: 9$.

The representative TEM image of the as-prepared $\left(\mathrm{Ag}_{0.7} \mathrm{Pt}_{0.3}\right)_{0.001} / \mathrm{Bi}_{4} \mathrm{Ti}_{3} \mathrm{O}_{12}$ photocatalyst is shown in Figure $3 a$, confirming that $\left(\mathrm{Ag}_{0.7} \mathrm{Pt}_{0.3}\right)_{0.001} / \mathrm{Bi}_{4} \mathrm{Ti}_{3} \mathrm{O}_{12}$ photocatalyst exhibited a nano-sheet structure with proper thickness. As can be seen from the SAED pattern (Figure 3b), single crystalline $\mathrm{Bi}_{4} \mathrm{Ti}_{3} \mathrm{O}_{12}$ was prepared. Figure $3 \mathrm{c}$ obviously showed that $\mathrm{Ag}$ and Pt NPs were modified on the surface of the $\left(\mathrm{Ag}_{0.7} \mathrm{Pt}_{0.3}\right)_{0.001} / \mathrm{Bi}_{4} \mathrm{Ti}_{3} \mathrm{O}_{12}$ sample (dashed area). Furthermore, two different $\mathrm{d}$-spacing values of $0.226 \mathrm{~nm}$ and $0.239 \mathrm{~nm}$ were calculated from the lattice fringes of loaded particles (Figure 3d), which respectively correspond to the (111) crystal plane of cubic Pt and the (111) crystal plane of metallic Ag [28,29]. Figures 4-6 respectively presented the TEM images and the corresponding EDS elemental mapping images of $\left(\mathrm{Ag}_{0.7} \mathrm{Pt}_{0.3}\right)_{0.001} / \mathrm{Bi}_{4} \mathrm{Ti}_{3} \mathrm{O}_{12}, \mathrm{Ag}_{0.001} / \mathrm{Bi}_{4} \mathrm{Ti}_{3} \mathrm{O}_{12}$, and $\mathrm{Pt}_{0.001} / \mathrm{Bi}_{4} \mathrm{Ti}_{3} \mathrm{O}_{12}$ photocatalysts prepared by photoreduction method. It can be clearly seen from Figure $4 \mathrm{a}$ that a large amount of spherical particles with an average size of $9 \mathrm{~nm}$ were randomly distributed over the surface of as-prepared $\mathrm{Bi}_{4} \mathrm{Ti}_{3} \mathrm{O}_{12}$. EDS mapping results presented in Figure $4 \mathrm{~b}-\mathrm{f}$ indicated that the spherical particles were $\mathrm{Ag}$ and $\mathrm{Pt} \mathrm{NPs}$, confirming $\left(\mathrm{Ag}_{0.7} \mathrm{Pt}_{0.3}\right)_{0.001} / \mathrm{Bi}_{4} \mathrm{Ti}_{3} \mathrm{O}_{12}$ composite photocatalysts were successfully prepared. Similarly, Figures 5 and 6 separately proved that $\mathrm{Ag}_{0.001} / \mathrm{Bi}_{4} \mathrm{Ti}_{3} \mathrm{O}_{12}$ and $\mathrm{Pt}_{0.001} / \mathrm{Bi}_{4} \mathrm{Ti}_{3} \mathrm{O}_{12}$ were successfully synthesized. 

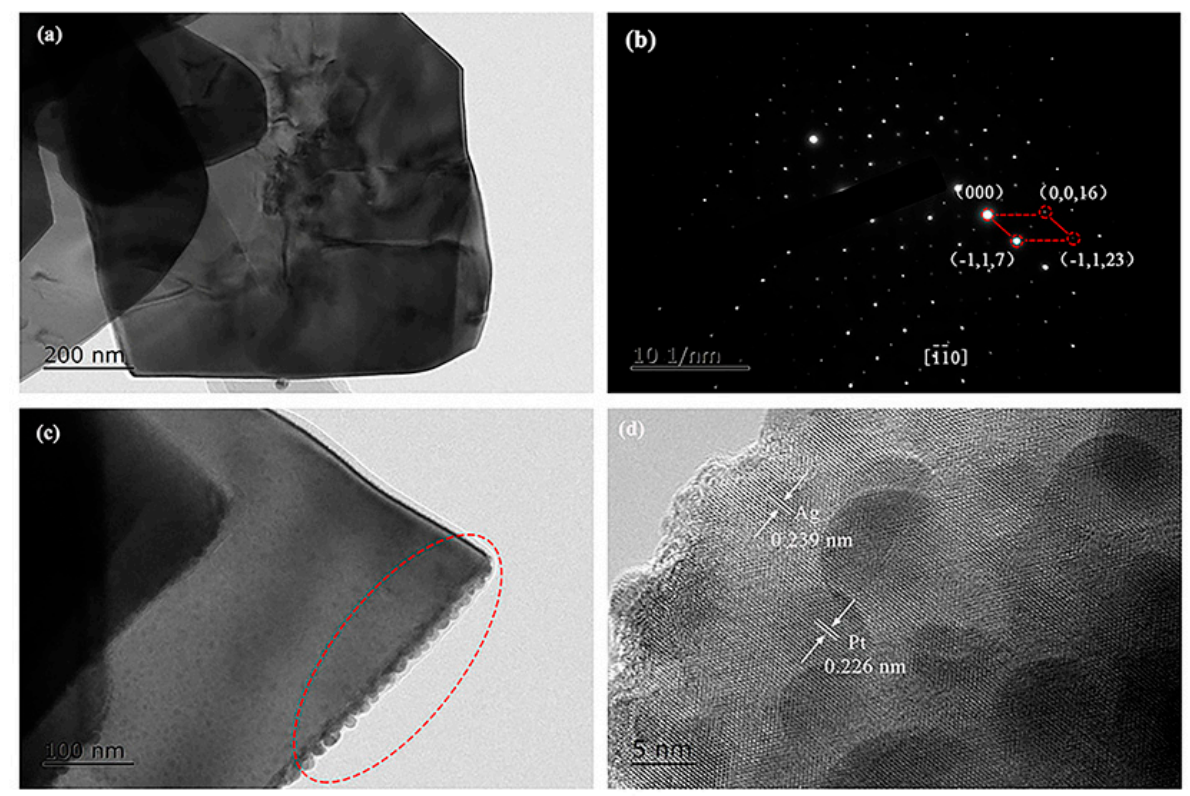

Figure 3. Transmission electron microscope (TEM) images $(\mathbf{a}, \mathbf{c})$, SAED image (b) and high-resolution TEM (HRTEM) image (d) of $\left(\mathrm{Ag}_{0.7} \mathrm{Pt}_{0.3}\right)_{0.001} / \mathrm{Bi}_{4} \mathrm{Ti}_{3} \mathrm{O}_{12}$.
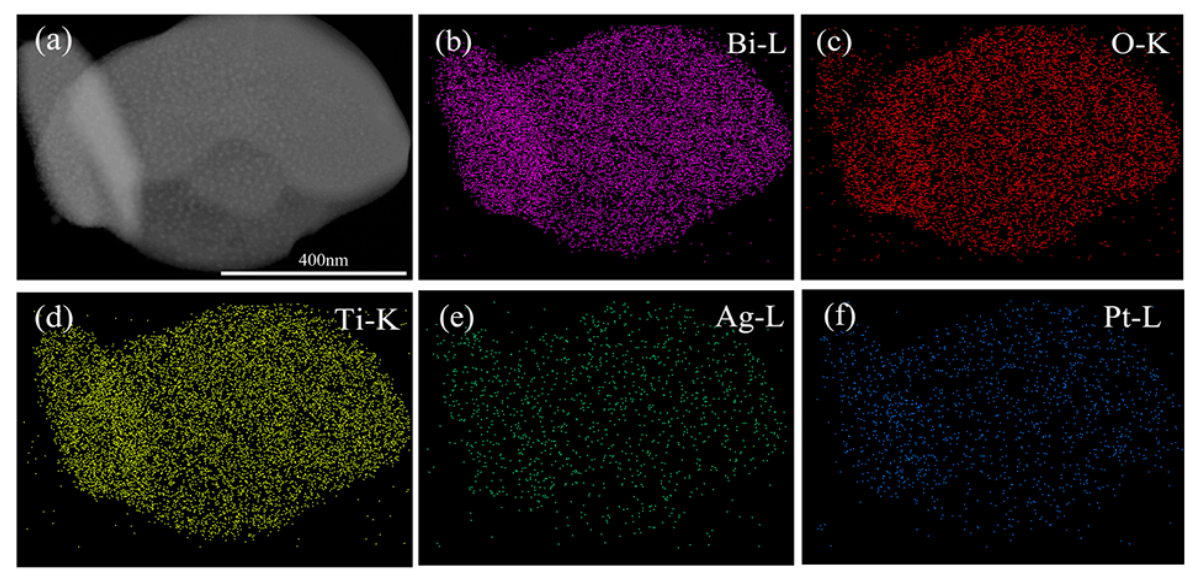

Figure 4. TEM image (a) and EDS maps of $\mathrm{Bi}, \mathrm{O}, \mathrm{Ti}, \mathrm{Ag}$ and $\mathrm{Pt}(\mathbf{b}-\mathbf{f})$ of as-prepared $\left(\mathrm{Ag}_{0.7} \mathrm{Pt}_{0.3}\right)_{0.001} / \mathrm{Bi}_{4} \mathrm{Ti}_{3} \mathrm{O}_{12}$.
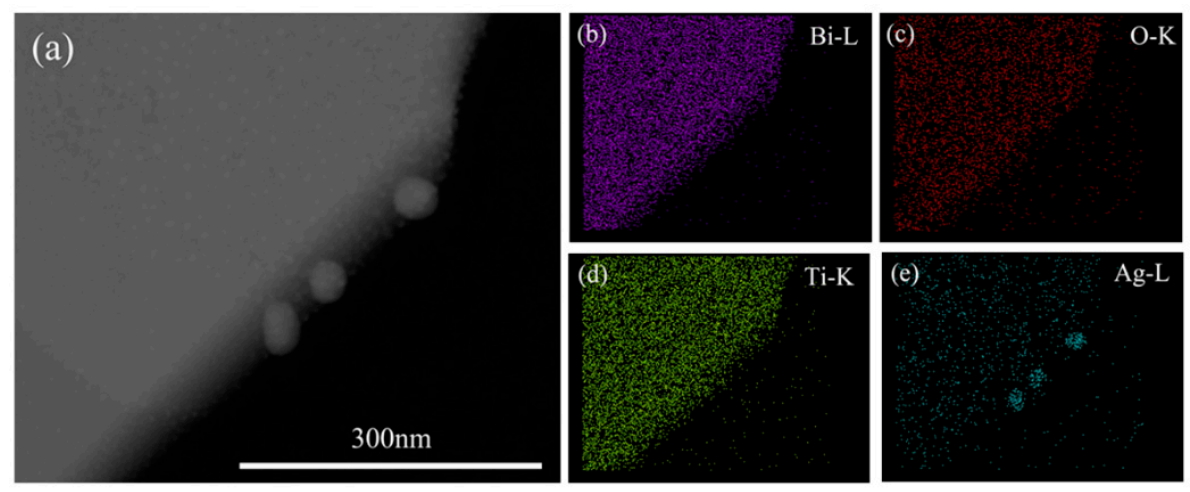

Figure 5. TEM image (a) and EDS maps of $\mathrm{Bi}, \mathrm{O}$, Ti and $\mathrm{Ag}(\mathbf{b}-\mathbf{e})$ of as-prepared $\mathrm{Ag}_{0.001} / \mathrm{Bi}_{4} \mathrm{Ti}_{3} \mathrm{O}_{12}$. 

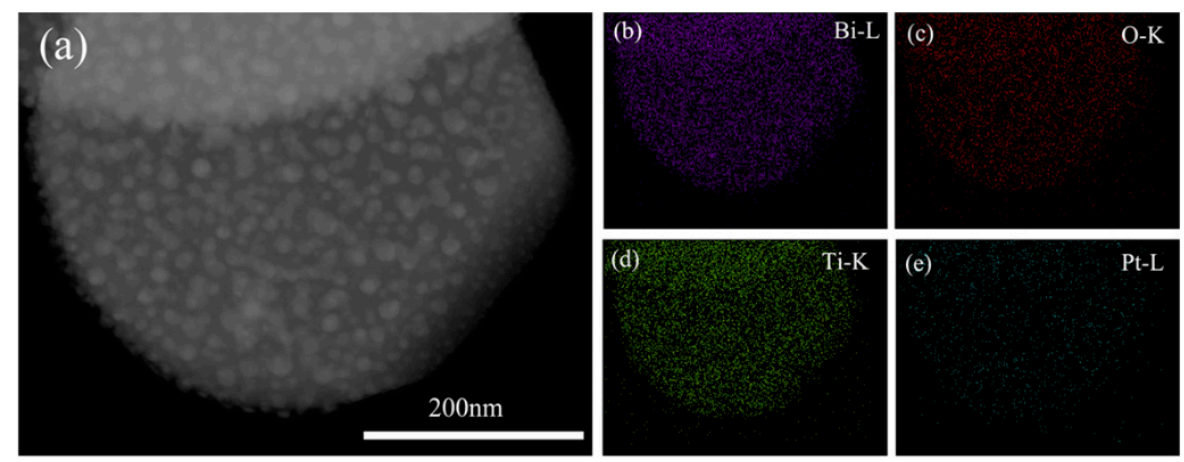

Figure 6. TEM image (a) and EDS maps of $\mathrm{Bi}, \mathrm{O}$, Ti and $\mathrm{Pt}(\mathbf{b}-\mathbf{e})$ of as-prepared $\mathrm{Pt}_{0.001} / \mathrm{Bi}_{4} \mathrm{Ti}_{3} \mathrm{O}_{12}$.

ICP-MS results presented in Table 3 revealed that the content of $\mathrm{Ag}$ in $\mathrm{Ag}_{0.001} / \mathrm{Bi}_{4} \mathrm{Ti}_{3} \mathrm{O}_{12}$ and $\mathrm{Pt}$ in $\mathrm{Pt}_{0.001} / \mathrm{Bi}_{4} \mathrm{Ti}_{3} \mathrm{O}_{12}$ photocatalysts was respectively $0.0347 \mathrm{wt} \%$ and $0.0782 \mathrm{wt} \%$, while the content of $\mathrm{Ag}$ and $\mathrm{Pt}$ in $\left(\mathrm{Ag}_{0.7} \mathrm{Pt}_{0.3}\right)_{0.001} / \mathrm{Bi}_{4} \mathrm{Ti}_{3} \mathrm{O}_{12}$ was respectively $0.0122 \mathrm{wt} \%$ and $0.0144 \mathrm{wt} \%$, demonstrating that $\mathrm{Ag}$ and $\mathrm{Pt}$ have been successfully loaded on $\mathrm{Bi}_{4} \mathrm{Ti}_{3} \mathrm{O}_{12}$ nanosheets. However, the actual amount was lower than that theoretical value, indicating that the $\mathrm{Ag}^{+}$and $\mathrm{Pt}^{4+}$ were not completely photo-reduced and loaded on $\mathrm{Bi}_{4} \mathrm{Ti}_{3} \mathrm{O}_{12}$ under present irradiation of Xe lamp.

Table 3. The content of $\mathrm{Ag}$ and $\mathrm{Pt}$ in the as-prepared photocatalysts.

\begin{tabular}{ccc}
\hline As-Prepared Photocatalyst & Element & Content (wt\%) \\
\hline $\mathrm{Ag}_{0.001} / \mathrm{Bi}_{4} \mathrm{Ti}_{3} \mathrm{O}_{12}$ & $\mathrm{Ag}$ & 0.0347 \\
\hline $\mathrm{Pt}_{0.001} / \mathrm{Bi}_{4} \mathrm{Ti}_{3} \mathrm{O}_{12}$ & $\mathrm{Pt}$ & 0.0782 \\
\hline$\left(\mathrm{Ag}_{0.7} \mathrm{Pt}_{0.3}\right)_{0.001} / \mathrm{Bi}_{4} \mathrm{Ti}_{3} \mathrm{O}_{12}$ & $\mathrm{Ag}$ & 0.0122 \\
\cline { 2 - 3 } & $\mathrm{Pt}$ & 0.0144 \\
\hline
\end{tabular}

XPS was performed to investigate the elemental information of as-prepared $\left(\mathrm{Ag}_{0.7} \mathrm{Pt}_{0.3}\right)_{0.001} / \mathrm{Bi}_{4} \mathrm{Ti}_{3} \mathrm{O}_{12}$ photocatalyst. As shown in Figure 7a, Bi, Ti, O, Ag and Pt elements were identified, demonstrating the successful preparation of the $\left(\mathrm{Ag}_{0.7} \mathrm{Pt}_{0.3}\right)_{0.001} / \mathrm{Bi}_{4} \mathrm{Ti}_{3} \mathrm{O}_{12}$ composite photocatalyst. The high-resolution XPS spectrum of Bi-4f, Ti-2p, O-1s, Ag-3d and Pt-4f were investigated (Figure 7b-f). Two peaks at 159.2 and $164.5 \mathrm{eV}$ were respectively ascribed to $\mathrm{Bi} 4 \mathrm{f}_{7 / 2}$ and $\mathrm{Bi} 4 \mathrm{f}_{5 / 2}$ (Figure $7 \mathrm{~b}$ ), indicating that only $\mathrm{Bi}^{3+}$ existed in the $\left(\mathrm{Ag}_{0.7} \mathrm{Pt}_{0.3}\right)_{0.001} / \mathrm{Bi}_{4} \mathrm{Ti}_{3} \mathrm{O}_{12}$ composite [30-32]. The high resolution XPS spectrum of Ti $2 \mathrm{p}$ can be deconvoluted into three peaks at $458.1 \mathrm{eV}, 463.8 \mathrm{eV}$ and $466.2 \mathrm{eV}$ (Figure 7c), which were assigned to $\mathrm{Ti} 2 \mathrm{P}_{3 / 2}$, Ti $2 \mathrm{p}_{1 / 2}$ and $\mathrm{Bi} 4 \mathrm{~d}_{3 / 2}$, respectively [30-32], demonstrating that only $\mathrm{Ti}^{4+}$ specie existed in the $\left(\mathrm{Ag}_{0.7} \mathrm{Pt}_{0.3}\right)_{0.001} / \mathrm{Bi}_{4} \mathrm{Ti}_{3} \mathrm{O}_{12}$ composite. From the high-resolution XPS spectrum of $\mathrm{O} 1 \mathrm{~s}$ (Figure $7 \mathrm{~d}$ ), the peak at $529.9 \mathrm{eV}$ was assigned to lattice oxygen in $\mathrm{Bi}_{4} \mathrm{Ti}_{3} \mathrm{O}_{12}$ and the peak at $532.2 \mathrm{eV}$ was ascribed to the oxygen adsorbed on the surface of as-prepared $\left(\mathrm{Ag}_{0.7} \mathrm{Pt}_{0.3}\right)_{0.001} / \mathrm{Bi}_{4} \mathrm{Ti}_{3} \mathrm{O}_{12}$ [30]. As shown in Figure 7e, peaks at 368.1 and $374.1 \mathrm{eV}$ were, respectively, assigned to $\mathrm{Ag} 3 \mathrm{~d}_{5 / 2}$ and $\mathrm{Ag} 3 \mathrm{~d}_{3 / 2}$, providing conclusive evidence for $\mathrm{Ag}$ metal in the as-prepared $\left(\mathrm{Ag}_{0.7} \mathrm{Pt}_{0.3}\right)_{0.001} / \mathrm{Bi}_{4} \mathrm{Ti}_{3} \mathrm{O}_{12}$ photocatalyst. As presented in Figure $7 \mathrm{f}$, an asymmetric peak at $74.35 \mathrm{eV}$ assigned to $\mathrm{Pt} 4 \mathrm{f}_{5 / 2}$ was observed, illustrating the existence of $\mathrm{Pt}$ metal in the as-prepared $\left(\mathrm{Ag}_{0.7} \mathrm{Pt}_{0.3}\right)_{0.001} / \mathrm{Bi}_{4} \mathrm{Ti}_{3} \mathrm{O}_{12}$ sample $[33,34]$. Since no additional peaks were observed in the $\mathrm{Ag} 3 \mathrm{~d}$ and $\mathrm{Pt} 4 \mathrm{f}$ spectra, it can be determined that $\mathrm{Ag}$ and $\mathrm{Pt}$ do not exist in the form of oxidation states.

Fourier transform infrared (FTIR) spectra further offered the functional group information of the $\mathrm{Bi}_{4} \mathrm{Ti}_{3} \mathrm{O}_{12}$ and $\left(\mathrm{Ag}_{0.7} \mathrm{Pt}_{0.3}\right)_{0.001} / \mathrm{Bi}_{4} \mathrm{Ti}_{3} \mathrm{O}_{12}$ (Figure 8). The peak at $832 \mathrm{~cm}^{-1}$ belonged to the $\mathrm{Bi}-\mathrm{O}$ characteristic stretching vibration, the strong peak at $573 \mathrm{~cm}^{-1}$ and the weak peak at $472 \mathrm{~cm}^{-1}$ belonged to the stretching vibration of Ti-O $[35,36]$. These results indicated that the structure of orthorhombic phase $\mathrm{Bi}_{4} \mathrm{Ti}_{3} \mathrm{O}_{12}$ was not damaged by loading of Ag and Pt NPs. Besides, no characteristic peaks 
of $\mathrm{Pt}$ and $\mathrm{Ag}$ oxides were observed, indicating that both $\mathrm{Pt}$ and $\mathrm{Ag}$ existed in metallic state in $\left(\mathrm{Ag}_{0.7} \mathrm{Pt}_{0.3}\right)_{0.001} / \mathrm{Bi}_{4} \mathrm{Ti}_{3} \mathrm{O}_{12}$, which was in line with the XPS results presented the Figure 7.
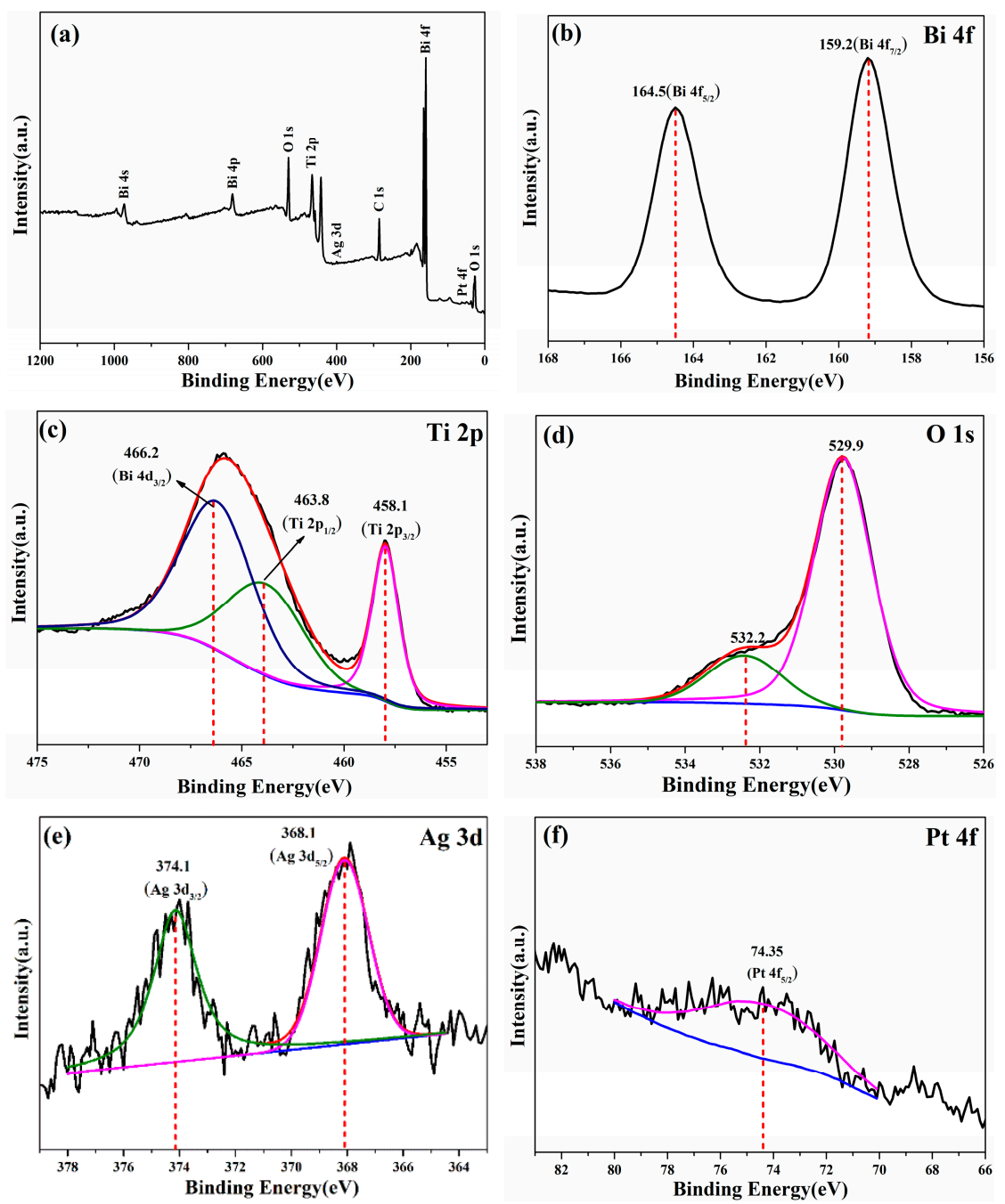

Figure 7. (a) X-ray photoelectron spectroscopy (XPS) survey scan spectrum and (b-f) high resolution XPS spectra of Bi 4f, Ti 2p, O 1s, Ag 3d and Pt 4 f of $\left(\mathrm{Ag}_{0.7} \mathrm{Pt}_{0.3}\right)_{0.001} / \mathrm{Bi}_{4} \mathrm{Ti}_{3} \mathrm{O}_{12}$.

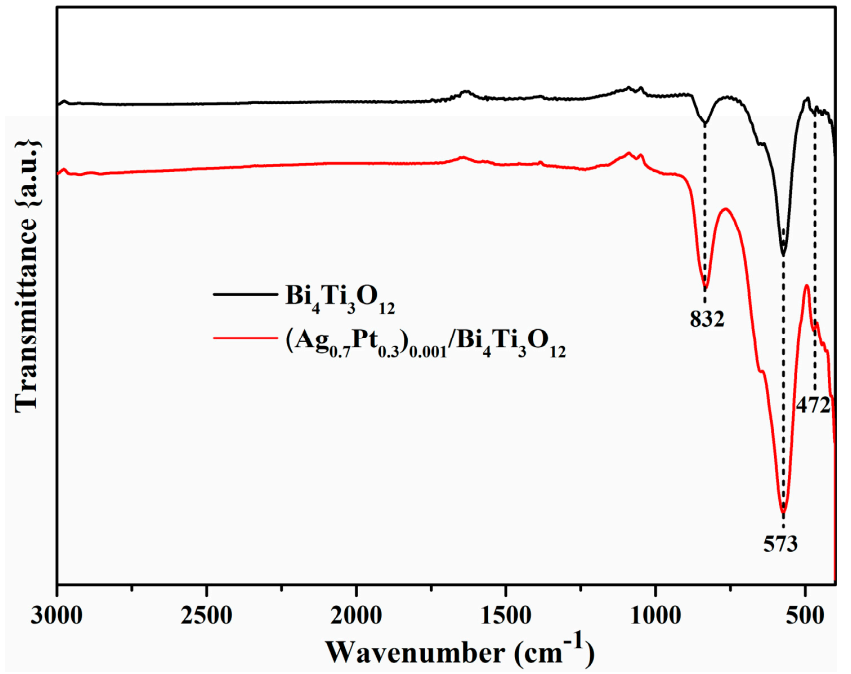

Figure 8. Fourier transform infrared (FTIR) spectra of $\mathrm{Bi}_{4} \mathrm{Ti}_{3} \mathrm{O}_{12}$ and $\left(\mathrm{Ag}_{0.7} \mathrm{Pt}_{0.3}\right)_{0.001} / \mathrm{Bi}_{4} \mathrm{Ti}_{3} \mathrm{O}_{12}$. 
Figure 9 showed the UV-Vis absorption spectra of pristine $\mathrm{Bi}_{4} \mathrm{Ti}_{3} \mathrm{O}_{12}$ and as-prepared $(\mathrm{AgPt})_{0.001} / \mathrm{Bi}_{4} \mathrm{Ti}_{3} \mathrm{O}_{12}$ composites. Obviously, $(\mathrm{AgPt})_{0.001} / \mathrm{Bi}_{4} \mathrm{Ti}_{3} \mathrm{O}_{12}$ composites exhibited stronger visible light absorption than pristine $\mathrm{Bi}_{4} \mathrm{Ti}_{3} \mathrm{O}_{12}$. As reported in previous works, the enhancement in visible light absorption may be dominated by the surface plasma resonance effect of $\mathrm{Ag}$ and $\mathrm{Pt}$ NPs $[37,38]$. When the internal electron oscillation frequency of the AgPt bimetallic NPs was equal to the frequency of the irradiated light, local surface plasmon resonance was induced and then the visible light absorption of $(\mathrm{AgPt})_{0.001} / \mathrm{Bi}_{4} \mathrm{Ti}_{3} \mathrm{O}_{12}$ was improved. Meanwhile, no obvious change was observed in the absorption edge for all $(\mathrm{AgPt})_{0.001} / \mathrm{Bi}_{4} \mathrm{Ti}_{3} \mathrm{O}_{12}$ samples, suggesting that the bandgap of $\mathrm{Bi}_{4} \mathrm{Ti}_{3} \mathrm{O}_{12}$ and $(\mathrm{AgPt})_{0.001} / \mathrm{Bi}_{4} \mathrm{Ti}_{3} \mathrm{O}_{12}$ photocatalysts was almost the same.

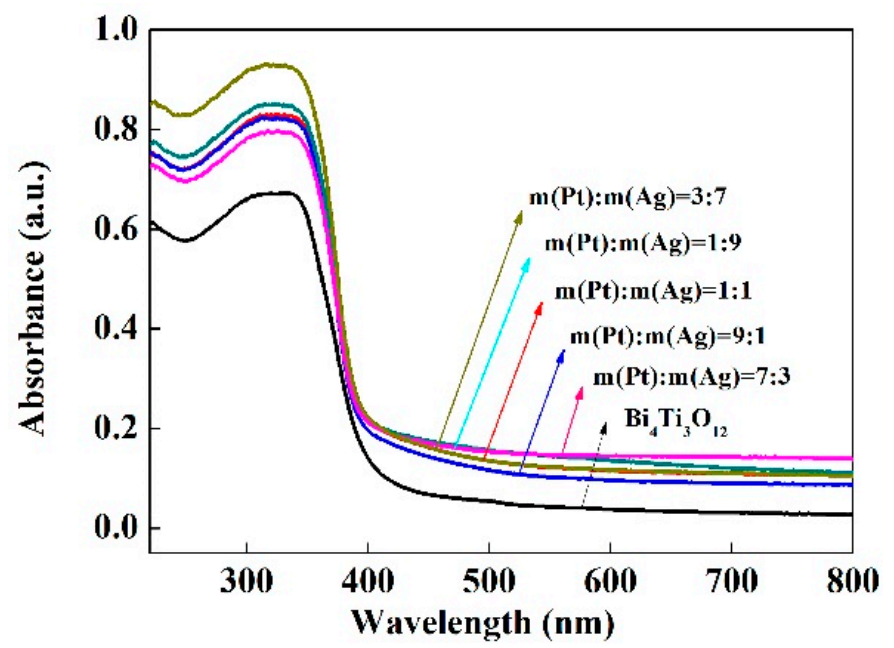

Figure 9. Ultraviolet-visible (UV-Vis) absorption spectra of starting $\mathrm{Bi}_{4} \mathrm{Ti}_{3} \mathrm{O}_{12}$ and $(\mathrm{AgPt})_{0.001} / \mathrm{Bi}_{3} \mathrm{Ti}_{4} \mathrm{O}_{12}$ composite photocatalysts prepared by photoreduction method.

Figure 10a showed the dependence of $C / C_{0}\left(C_{0}\right.$ and $C$ are respectively the initial and instantaneous concentration of the $\mathrm{RhB}$ solution) on irradiation time during the RhB degradation process when $\mathrm{Bi}_{4} \mathrm{Ti}_{3} \mathrm{O}_{12}$ and $(\mathrm{AgPt})_{0.001} / \mathrm{Bi}_{4} \mathrm{Ti}_{3} \mathrm{O}_{12}$ were used as photocatalysts. It can be seen that the degradation rate $\left(\left(C_{0}-C\right) / C_{0} \times 100 \%\right)$ of $\mathrm{RhB}$ increased from about $69.7 \%$ to about $91.5 \%$ after irradiation of $90 \mathrm{~min}$ when $0.1 \mathrm{wt} \% \mathrm{Ag}_{0.7} \mathrm{Pt}_{0.3}$ bimetallic NPs were loaded on $\mathrm{Bi}_{4} \mathrm{Ti}_{3} \mathrm{O}_{12}$. Additionally, the photocatalytic activity of $(\mathrm{AgPt})_{0.001} / \mathrm{Bi}_{4} \mathrm{Ti}_{3} \mathrm{O}_{12}$ was monitored by varying the mass ratio of $\mathrm{Ag}$ to $\mathrm{Pt}$, and the $\left(\mathrm{Ag}_{0.7} \mathrm{Pt}_{0.3}\right)_{0.001} / \mathrm{Bi}_{4} \mathrm{Ti}_{3} \mathrm{O}_{12}$ catalysts displayed the best photocatalytic activity for RhB degradation.
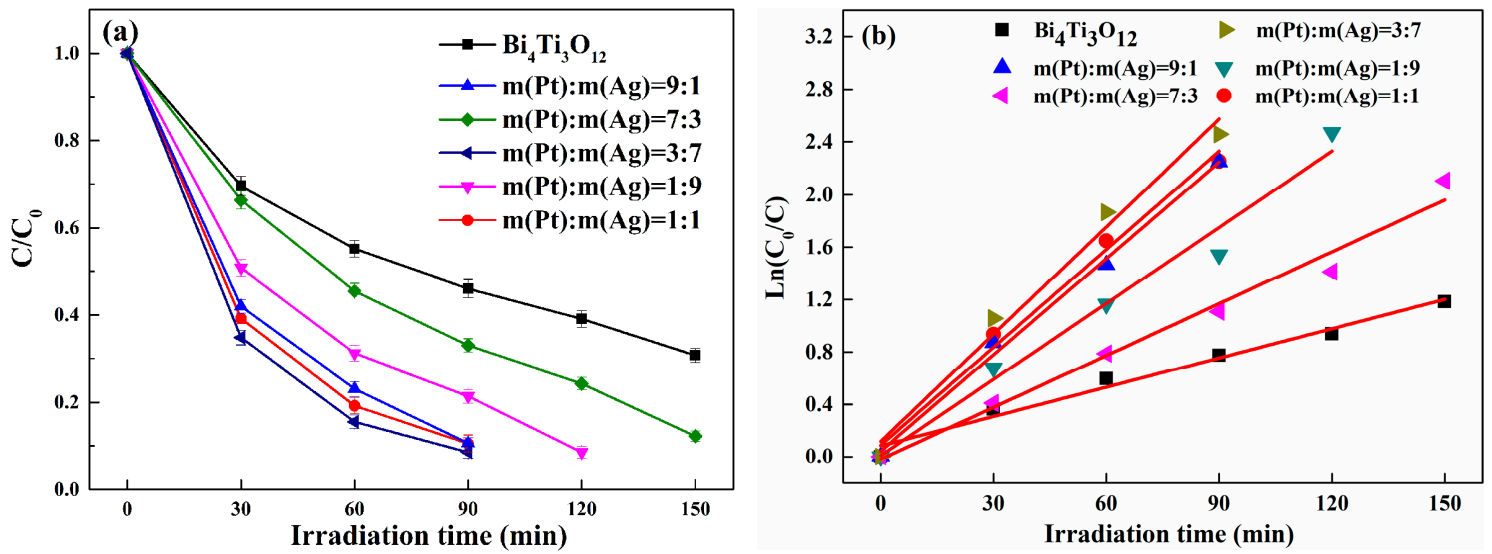

Figure 10. (a) Photocatalytic activity of pristine $\mathrm{Bi}_{4} \mathrm{Ti}_{3} \mathrm{O}_{12}$ and as-prepared $(\mathrm{AgPt})_{0.001} / \mathrm{Bi}_{4} \mathrm{Ti}_{3} \mathrm{O}_{12}$ composite photocatalysts prepared by photocatalytic reduction method on the degradation of rhodamine $\mathrm{B}(\mathrm{RhB})$; (b) plot of $\operatorname{Ln}\left(\mathrm{C}_{0} / \mathrm{C}\right)$ versus irradiation time for the photodegradation of $\mathrm{RhB}$. 
In order to investigate the reaction kinetics of $\mathrm{Bi}_{4} \mathrm{Ti}_{3} \mathrm{O}_{12}$ and $(\mathrm{AgPt})_{0.001} / \mathrm{Bi}_{4} \mathrm{Ti}_{3} \mathrm{O}_{12}$ photocatalysts for RhB degradation, relationship between $\operatorname{Ln}\left(\mathrm{C}_{0} / \mathrm{C}\right)$ and irradiation time was measured and the results were shown in Figure 10b. All the photocatalytic reactions can be fitted well by pseudo-first-order kinetics,

$$
\operatorname{Ln}\left(\mathrm{C} / \mathrm{C}_{0}\right)=-\mathrm{kt}
$$

When $\operatorname{Ln}\left(\mathrm{C} / \mathrm{C}_{0}\right)$ was plotted versus irradiation time $\mathrm{t}$, the apparent reaction rate $\mathrm{k}$ can be obtained by calculating the slope of the fitted curves. The results shown in Figure $10 \mathrm{~b}$ demonstrate that the $\mathrm{k}$ value relied heavily on the loading of AgPt bimetallic particles, and that the highest $\mathrm{k}$ value of $\mathrm{RhB}$ degradation catalyzed by $\left(\mathrm{Ag}_{0.7} \mathrm{Pt}_{0.3}\right)_{0.001} / \mathrm{Bi}_{4} \mathrm{Ti}_{3} \mathrm{O}_{12}$ was calculated as $0.027 \mathrm{~min}^{-1}$, which was 3.7 times of that by $\mathrm{Bi}_{4} \mathrm{Ti}_{3} \mathrm{O}_{12}$.

The photocatalytic activities of $\mathrm{Ag}_{0.001} / \mathrm{Bi}_{3} \mathrm{Ti}_{4} \mathrm{O}_{12}$ and $\mathrm{Pt}_{0.001} / \mathrm{Bi}_{3} \mathrm{Ti}_{4} \mathrm{O}_{12}$ composite photocatalysts prepared by the photocatalytic reduction method on the degradation of RhB after a 150 min illumination were also investigated (Figure 11). Figure 11a revealed that the degradation rate of RhB catalyzed by $\mathrm{Pt}_{0.001} / \mathrm{Bi}_{4} \mathrm{Ti}_{3} \mathrm{O}_{12}$ reached as high as $92.4 \%$, which was higher than that by $\mathrm{Ag}_{0.001} / \mathrm{Bi}_{4} \mathrm{Ti}_{3} \mathrm{O}_{12}$ (87.7\%) and by $\mathrm{Bi}_{4} \mathrm{Ti}_{3} \mathrm{O}_{12}$ (69.3\%). Meanwhile, the apparent reaction rate $\mathrm{k}$ in the $\mathrm{Pt}_{0.001} / \mathrm{Bi}_{4} \mathrm{Ti}_{3} \mathrm{O}_{12}$ and $\mathrm{Ag}_{0.001} / \mathrm{Bi}_{4} \mathrm{Ti}_{3} \mathrm{O}_{12}$ catalyzed system was separately calculated as $0.01561 \mathrm{~min}^{-1}$ and $0.01366 \mathrm{~min}^{-1}$ which was, respectively, 2.1 and 1.8 times that in $\mathrm{Bi}_{4} \mathrm{Ti}_{3} \mathrm{O}_{12}$ case (Figure 11b). And excitingly, $(\mathrm{AgPt})_{0.001} / \mathrm{Bi}_{4} \mathrm{Ti}_{3} \mathrm{O}_{12}$ composites displayed higher photocatalytic activity towards RhB degradation than $\mathrm{Ag}_{0.001} / \mathrm{Bi}_{4} \mathrm{Ti}_{3} \mathrm{O}_{12}$ and $\mathrm{Pt}_{0.001} / \mathrm{Bi}_{4} \mathrm{Ti}_{3} \mathrm{O}_{12}$. The reasons may be as follows: (i) the surface plasma resonance effect of $\mathrm{Ag}$ and Pt NPs enhanced the visible light absorption (Figure 8) [34]; (ii) Ag NPs can be used as electronic acceptors with excellent electrical conductivity to promote the separation of electron-hole pairs; and (iii) Pt NPs can be applied as electron cocatalyst to accelerate the capture of photogenerated electron, and then facilitated the proton reduction reaction $[39,40]$.
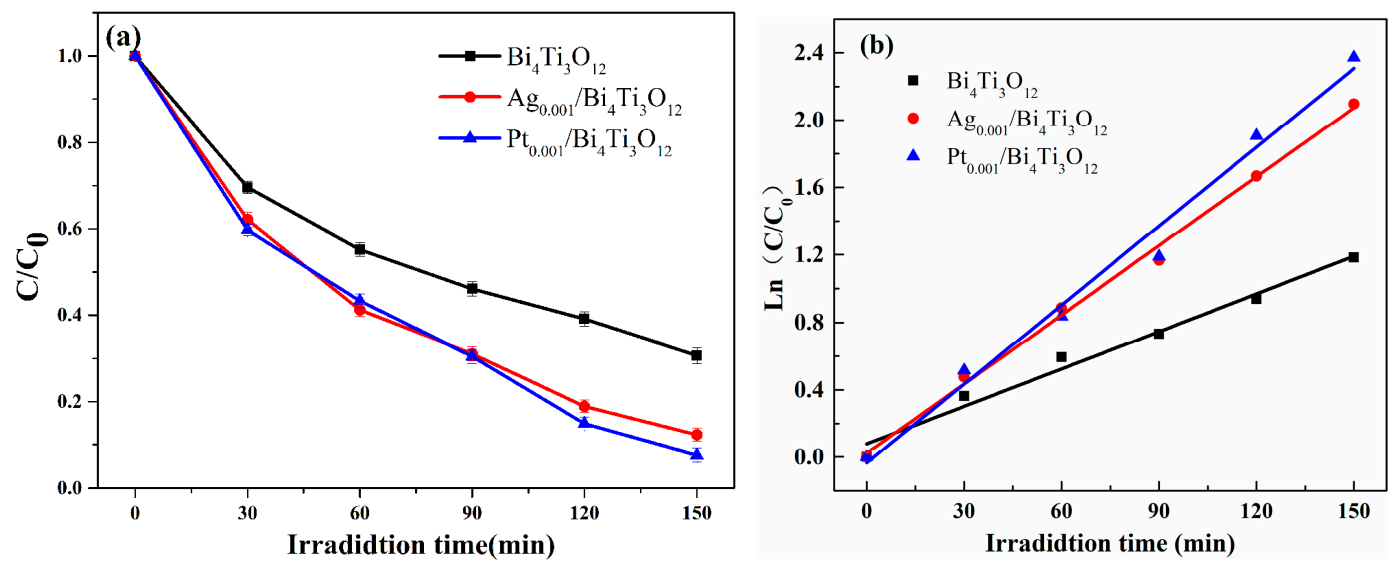

Figure 11. (a) Photocatalytic activity of pristine $\mathrm{Bi}_{4} \mathrm{Ti}_{3} \mathrm{O}_{12}, \mathrm{Ag}_{0.001} / \mathrm{Bi}_{3} \mathrm{Ti}_{4} \mathrm{O}_{12}$ and $\mathrm{Pt}_{0.001} / \mathrm{Bi}_{3} \mathrm{Ti}_{4} \mathrm{O}_{12}$ composite photocatalysts prepared by photocatalytic reduction method on the degradation of RhB; (b) plot of $\operatorname{Ln}\left(\mathrm{C}_{0} / \mathrm{C}\right)$ versus irradiation time for the photodegradation of $\mathrm{RhB}$.

Hole and radical trapping experiments were carried out to investigate the effective reactants in the photocatalytic RhB degradation process. TEOA, EtOH and BQ were respectively added to RhB solution as capture agents for $\mathrm{h}^{+}, \bullet \mathrm{OH}$, and $\bullet \mathrm{O}^{2-}$ scavengers [41,42]. The main active species were determined by the change of degradation effect after the photocatalysis experiment. As can be seen from Figure 12a, the photocatalytic performance of RhB removal was almost unchanged by introducing $\mathrm{EtOH}$, implying that $\bullet \mathrm{OH}$ played a tiny effect on the degradation of RhB. By contrast, after adding TEOA or $\mathrm{BQ}$, the photocatalytic RhB degradation activity of $\left(\mathrm{Ag}_{0.7} \mathrm{Pt}_{0.3}\right)_{0.001} / \mathrm{Bi}_{4} \mathrm{Ti}_{3} \mathrm{O}_{12}$ was remarkably suppressed and the corresponding efficiencies for photodegradation of RhB were calculated as low as $9.4 \%$ or $10.8 \%$, respectively (Figure $12 \mathrm{~b}$ ). It can thus be reasonably concluded that $\mathrm{h}^{+}$and $\bullet \mathrm{O}^{2-}$ were the active groups in the present $\left(\mathrm{Ag}_{0.7} \mathrm{Pt}_{0.3}\right)_{0.001} / \mathrm{Bi}_{4} \mathrm{Ti}_{3} \mathrm{O}_{12}$ photocatalyzed process. 

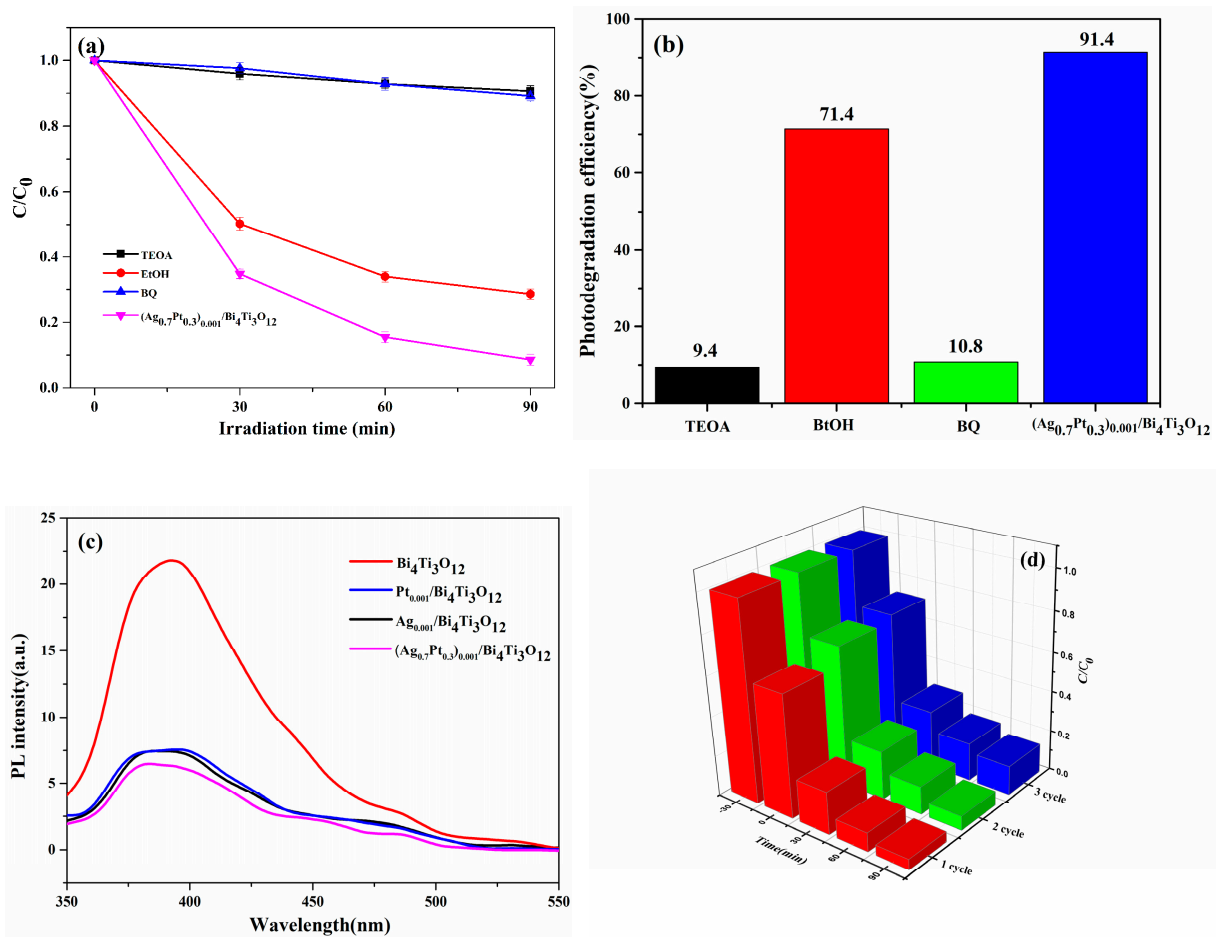

Figure 12. (a,b) Effects of various scavengers on the photocatalytic efficiency of $\left(\mathrm{Ag}_{0.7} \mathrm{Pt}_{0.3}\right)_{0.001} / \mathrm{Bi}_{4} \mathrm{Ti}_{3} \mathrm{O}_{12}$; (c) photoluminescence spectra of $\mathrm{Bi}_{4} \mathrm{Ti}_{3} \mathrm{O}_{12}$ and $\mathrm{AgPt} / \mathrm{Bi}_{4} \mathrm{Ti}_{3} \mathrm{O}_{12} ;$ (d) Cyclic photodegradation of $\mathrm{RhB}$ by $\left(\mathrm{Ag}_{0.7} \mathrm{Pt}_{0.3}\right)_{0.001} / \mathrm{Bi}_{4} \mathrm{Ti}_{3} \mathrm{O}_{12}$ photocatalyst.

In order to study the separation behavior of electron hole pairs, photoluminescence (PL) spectroscopy was implemented. As shown in Figure 12c, phase pure $\mathrm{Bi}_{4} \mathrm{Ti}_{3} \mathrm{O}_{12}, \mathrm{Pt}_{0.001} / \mathrm{Bi}_{4} \mathrm{Ti}_{3} \mathrm{O}_{12}$, $\mathrm{Ag}_{0.001} / \mathrm{Bi}_{4} \mathrm{Ti}_{3} \mathrm{O}_{12}$ and $\left(\mathrm{Ag}_{0.7} \mathrm{Pt}_{0.3}\right)_{0.001} / \mathrm{Bi}_{4} \mathrm{Ti}_{3} \mathrm{O}_{12}$ samples exhibit a similar PL emission curve when they were excited by a $320 \mathrm{~nm}$ light. However, even though the characteristic peaks of the four PL curves were all observed at about $400 \mathrm{~nm}$, the PL spectroscopy of $\left(\mathrm{Ag}_{0.7} \mathrm{Pt}_{0.3}\right)_{0.001} / \mathrm{Bi}_{4} \mathrm{Ti}_{3} \mathrm{O}_{12}$ composite exhibited the lowest emission intensity, illustrating that the separation rate of photogenerated electron hole pairs in the $\left(\mathrm{Ag}_{0.7} \mathrm{Pt}_{0.3}\right)_{0.001} / \mathrm{Bi}_{4} \mathrm{Ti}_{3} \mathrm{O}_{12}$ sample was the highest [43,44]. As a result, more active species were formed to participate in the degradation of $\mathrm{RhB}$ in the case.

The stability of the photocatalyst was very important for its practical application. Therefore, the cycle experiment of $\mathrm{RhB}$ degradation was implemented (Figure 12d). To our amazement, the $\mathrm{RhB}$ degradation efficiency excited by $\left(\mathrm{Ag}_{0.7} \mathrm{Pt}_{0.3}\right)_{0.001} / \mathrm{Bi}_{4} \mathrm{Ti}_{3} \mathrm{O}_{12}$ photocatalyst decreased slightly after three consecutive cycles. This demonstrated that the as-prepared $\left(\mathrm{Ag}_{0.7} \mathrm{Pt}_{0.3}\right)_{0.001} / \mathrm{Bi}_{4} \mathrm{Ti}_{3} \mathrm{O}_{12}$ catalyst had good photocatalytic stability for degradation of RhB.

Based on the results obtained, a possible degradation mechanism of RhB degradation over $\mathrm{AgPt} / \mathrm{Bi}_{4} \mathrm{Ti}_{3} \mathrm{O}_{12}$ was proposed (Figure 13) and described as follows: (i) under the irradiation of light, photogenerated electrons $\mathrm{e}^{-}$and holes $\mathrm{h}^{+}$were generated on the surface of $\mathrm{Bi}_{4} \mathrm{Ti}_{3} \mathrm{O}_{12}$ [45]. Generally, $\mathrm{h}^{+}$can react with $\mathrm{H}_{2} \mathrm{O}$ or $\mathrm{OH}^{-}$to form active hydroxyl $\bullet \mathrm{OH}$, $\mathrm{e}^{-}$can combine with $\mathrm{O}_{2}$ to produce superoxide radical $\bullet \mathrm{O}^{2-}$. Since $\mathrm{h}^{+}, \bullet \mathrm{OH}$ and $\bullet \mathrm{O}^{2-}$ all have strong oxidability, they can react directly with $\mathrm{RhB}$ to generate water, $\mathrm{CO}_{2}$ and inorganic small molecules [46-49]. However, the photogenerated $\mathrm{h}^{+}$and $\mathrm{e}^{-}$will recombine rapidly on the surface of $\mathrm{Bi}_{4} \mathrm{Ti}_{3} \mathrm{O}_{12}$ and then the photocatalytic activity was reduced; (ii) when Ag NPs were modified on the surface of $\mathrm{Bi}_{4} \mathrm{Ti}_{3} \mathrm{O}_{12}$, the photogenerated $\mathrm{h}^{+}$and $\mathrm{e}^{-}$ will be redistributed since the Fermi level of $\mathrm{Ag}$ was lower than that of $\mathrm{Bi}_{4} \mathrm{Ti}_{3} \mathrm{O}_{12}$ [50]. Due to the higher Fermi level of $\mathrm{Bi}_{4} \mathrm{Ti}_{3} \mathrm{O}_{12}$, photogenerated $\mathrm{e}^{-}$transferred from the surface of $\mathrm{Bi}_{4} \mathrm{Ti}_{3} \mathrm{O}_{12}$ to $\mathrm{Ag}$ NPs with lower Fermi level and thus Schottky barrier was formed on their interface [51]. Therefore, the photogenerated electrons $\mathrm{e}^{-}$were trapped and the recombination of photogenerated electron-hole pairs was inhibited $[34,38,52-54]$. As a result, more photogenerated $\mathrm{h}^{+}$was left to oxidize the $\mathrm{RhB}$ 
(Equations (2)-(10)); (iii) Pt NPs cocatalysts can provide adsorption sites for protons as electron sinks, and thus the number of $\mathrm{h}^{+}$was further improved [21] and (iv) due to the surface plasma resonance effect of $\mathrm{Ag}$ and Pt NPs, the absorption of visible light by $\mathrm{Bi}_{4} \mathrm{Ti}_{3} \mathrm{O}_{12}$ was greatly improved $[18,55]$, and more electrons and holes were generated. The reaction formulas were as follows:

$$
\begin{gathered}
\mathrm{Bi}_{4} \mathrm{Ti}_{3} \mathrm{O}_{12}+\mathrm{h} v \rightarrow \mathrm{Bi}_{4} \mathrm{Ti}_{3} \mathrm{O}_{12}\left(\mathrm{e}^{-}+\mathrm{h}^{+}\right) \\
\mathrm{Bi}_{4} \mathrm{Ti}_{3} \mathrm{O}_{12}\left(\mathrm{e}^{-}\right)+\mathrm{Ag} / \mathrm{Pt} \rightarrow \mathrm{Bi}_{4} \mathrm{Ti}_{3} \mathrm{O}_{12}+\mathrm{Ag} / \mathrm{Pt}\left(\mathrm{e}^{-}\right) \\
\mathrm{Bi}_{4} \mathrm{Ti}_{3} \mathrm{O}_{12}\left(\mathrm{~h}^{+}\right)+\mathrm{H}_{2} \mathrm{O} \rightarrow \bullet \mathrm{OH}+\mathrm{H}^{+} \\
\mathrm{Bi}_{4} \mathrm{Ti}_{3} \mathrm{O}_{12}\left(\mathrm{~h}^{+}\right)+\mathrm{OH}^{-} \rightarrow \bullet \mathrm{OH} \\
\mathrm{Bi}_{4} \mathrm{Ti}_{3} \mathrm{O}_{12}\left(\mathrm{e}^{-}\right)+\mathrm{O}_{2} \rightarrow \mathrm{Bi}_{4} \mathrm{Ti}_{3} \mathrm{O}_{12}+\bullet \mathrm{O}^{2-} \\
\mathrm{Ag} / \mathrm{Pt}\left(\mathrm{e}^{-}\right)+\mathrm{O}_{2} \rightarrow \mathrm{Ag} / \mathrm{Pt}+\bullet \mathrm{O}^{2-} \\
\bullet \mathrm{OH}+\mathrm{RhB} \rightarrow \mathrm{CO}_{2}+\mathrm{H}_{2} \mathrm{O}+ \\
\bullet \mathrm{O}^{2-}+\mathrm{RhB} \rightarrow \mathrm{CO}_{2}+\mathrm{H}_{2} \mathrm{O}+. . \\
\mathrm{Bi}_{4} \mathrm{Ti}_{3} \mathrm{O}_{12}\left(\mathrm{~h}^{+}\right)+\mathrm{RhB} \rightarrow \mathrm{CO}_{2}+\mathrm{H}_{2} \mathrm{O}+
\end{gathered}
$$

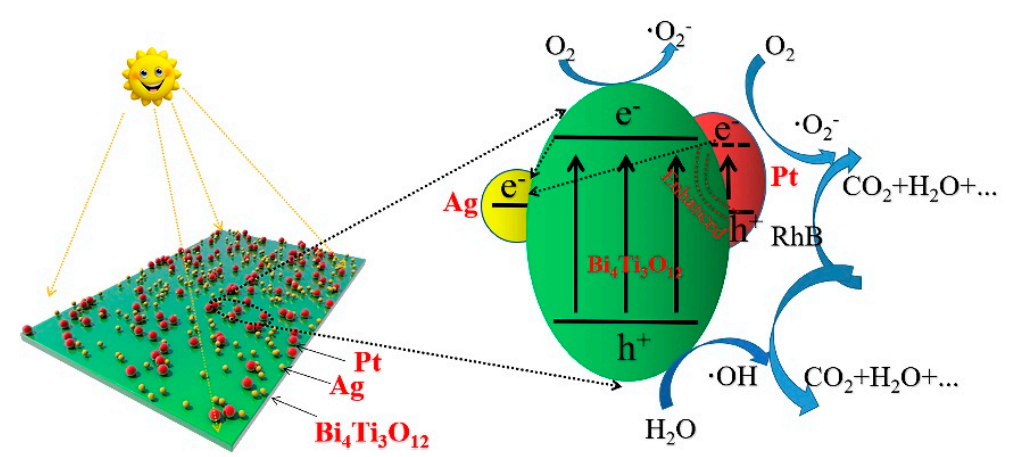

Figure 13. Proposed photocatalytic mechanism for degradation of $\mathrm{RhB}$ using as-prepared $\mathrm{AgPt} / \mathrm{Bi}_{4} \mathrm{Ti}_{3} \mathrm{O}_{12}$ composite photocatalysts.

\section{Conclusions}

$\mathrm{Bi}_{4} \mathrm{Ti}_{3} \mathrm{O}_{12}$ particles with lamellar structure were prepared firstly by a molten salt method as precursor, and then $\mathrm{Ag}, \mathrm{Pt}$ and $\mathrm{AgPt}$ bimetallic NPs were loaded on the as-prepared sheet-like $\mathrm{Bi}_{4} \mathrm{Ti}_{3} \mathrm{O}_{12}$ to synthesize $\mathrm{AgPt} / \mathrm{Bi}_{4} \mathrm{Ti}_{3} \mathrm{O}_{12}$ composites through the photoreduction procedure. The results revealed that the crystal structure and morphology of the as-prepared $\mathrm{Bi}_{4} \mathrm{Ti}_{3} \mathrm{O}_{12}$ were almost unchanged by loading $\mathrm{Ag}, \mathrm{Pt}$ and $\mathrm{AgPt}$ bimetallic NPs.

It is exciting to note that the photocatalytic activity of $\mathrm{Bi}_{4} \mathrm{Ti}_{3} \mathrm{O}_{12}$ for $\mathrm{RhB}$ degradation was sharply enhanced via loading Ag, Pt or AgPt bimetallic NPs. When the loading amount was fixed at $0.1 \mathrm{wt} \%$, the apparent reaction rate of the as-prepared $\mathrm{Ag} / \mathrm{Bi}_{4} \mathrm{Ti}_{3} \mathrm{O}_{12}$ and $\mathrm{Pt} / \mathrm{Bi}_{4} \mathrm{Ti}_{3} \mathrm{O}_{12}$ photocatalysts and $\mathrm{Ag}_{0.7} \mathrm{Pt}_{0.3} / \mathrm{Bi}_{4} \mathrm{Ti}_{3} \mathrm{O}_{12}$ composite photocatalysts was respectively calculated as $0.01366 \mathrm{~min}^{-1}$, $0.01561 \mathrm{~min}^{-1}$ and $0.027 \mathrm{~min}^{-1}$, which was respectively 1.8 times, 2.1 times and 3.7 times that of pristine $\mathrm{Bi}_{4} \mathrm{Ti}_{3} \mathrm{O}_{12}\left(0.00744 \mathrm{~min}^{-1}\right)$. The enhanced activity may be ascribed to the surface plasma resonance effect of noble metal and Schottky barrier formed on the interface between noble metal NPs and $\mathrm{Bi}_{4} \mathrm{Ti}_{3} \mathrm{O}_{12}$. The reactive species trapping experiment demonstrated that $\mathrm{h}^{+}$and $\bullet \mathrm{O}^{2-}$ played the main role in present $\left(\mathrm{Ag}_{0.7} \mathrm{Pt}_{0.3}\right)_{0.001} / \mathrm{Bi}_{4} \mathrm{Ti}_{3} \mathrm{O}_{12}$ photocatalyzed process, and the $\left(\mathrm{Ag}_{0.7} \mathrm{Pt}_{0.3}\right)_{0.001} / \mathrm{Bi}_{4} \mathrm{Ti}_{3} \mathrm{O}_{12}$ catalyst exhibited good photocatalytic stability for RhB degradation. 
Author Contributions: G.Y. and G.Z. did experimental work and wrote the paper; H.Z., F.L., S.Z., Q.J. and Z.H. designed and reviewed the manuscript and provided some suggestions; K.L., Y.C. and J.H. reviewed the manuscript assisted in the experimental work. All authors contributed to and critically reviewed the manuscript. H.Z. and F.L. made particularly major contributions to the writing and editing. All authors have read and agreed to the published version of the manuscript.

Funding: This work was financially supported by Natural Science Foundation of Jiangxi Province, China (Contract No. 20181BAB216006); National Natural Science Foundation of China (Grant No. 51702241, and 51872210); Program of Hubei Province, China (Contract No. 2017CFA004 and T201602).

Conflicts of Interest: The authors declare no conflict of interest.

\section{References}

1. Alansi, A.M.; Al-Qunaibit, M.; Alade, I.O.; Qahtan, T.F.; Saleh, T.A. Visible-light responsive BiOBr nanoparticles loaded on reduced graphene oxide for photocatalytic degradation of dye. J. Mol. Liq. 2018, 253, 297-304. [CrossRef]

2. Lam, S.M.; Sin, J.C.; Mohamed, A.R. A review on photocatalytic application of $\mathrm{g}-\mathrm{C}_{3} \mathrm{~N}_{4}$ /semiconductor (CNS) nanocomposites towards the erasure of dyeing wastewater. Mater. Sci. Semicond. Process. 2016, 47, 62. [CrossRef]

3. Zangeneh, H.; Zinatizadeh, A.; Habibi, M.; Akia, M.; Isa, M.H. Photocatalytic oxidation of organic dyes and pollutants in wastewater using different modified titanium dioxides: A comparative review. J. Ind. Eng. Chem. 2015, 26, 1-36. [CrossRef]

4. Chávez, A.; Gimeno, O.; Rey, A.; Pliego, G.; Oropesa, A.; Álvarez, P.; Beltrán, F. Treatment of highly polluted industrial wastewater by means of sequential aerobic biological oxidation-ozone based AOPs. Chem. Eng. J. 2019, 361, 89-98. [CrossRef]

5. Do, M.H.; Phan, N.H.; Nguyen, T.K.P.; Pham, T.T.S.; Nguyen, V.K.; Vu, T.T.T. Activated carbon $/ \mathrm{Fe}_{3} \mathrm{O}_{4}$ nanoparticle composite: Fabrication, methyl orange removal and regeneration by hydrogen peroxide. Chemosphere 2011, 85, 1269-1276. [CrossRef] [PubMed]

6. Forgacs, E.; Cserháti, T.; Oros, G. Removal of synthetic dyes from wastewaters: A review. Environ. Int. 2004, 30, 953-971. [CrossRef] [PubMed]

7. Sivakumar, P.; Murugesan, B.; Loganathan, A. A review on decolourisation of dyes by photodegradation using various bismuth catalysts. J. Taiwan Inst. Chem. Eng. 2014, 45, 2300-2306. [CrossRef]

8. Mahmood, T.; Wang, X.S.; Chen, C.C.; Ma, W.H. Photocatalytic degradation of persistent and toxic organic pollutants. Chin. J. Catal. 2007, 21, 1117. [CrossRef]

9. Xie, J.; Guo, N.; Liu, A.; Cao, Y.; Hu, J.; Jia, D. Simple solid-state synthesis of $\mathrm{BiOCl} / \mathrm{Bi}_{2} \mathrm{O}_{2} \mathrm{CO}_{3}$ heterojunction and its excellent photocatalytic degradation of RhB. J. Alloys Compd. 2019, 784, 377-385. [CrossRef]

10. Ji, Y.C.; Yang, R.Q.; Wang, L.W.; Song, G.X.; Wang, A.Z.; Lv, Y.W.; Gao, M.M.; Zhang, J.; Yu, X. Visible light active and noble metal free $\mathrm{Nb}_{4} \mathrm{~N}_{5} / \mathrm{TiO}_{2}$ nanobelt surface heterostructure for plasmonic enhanced solar water splitting. Chem. Eng. J. 2020, 402, 126226. [CrossRef]

11. Xian, T.; Yang, H.; Di, L.; Ma, J.; Zhang, H.; Dai, J. Photocatalytic reduction synthesis of $\mathrm{SrTiO}_{3}$-graphene nanocomposites and their enhanced photocatalytic activity. Nanoscale Res. Lett. 2014, 9, 327. [CrossRef] [PubMed]

12. Peng, H.; Liu, D.; Zheng, X.; Fu, X. N-Doped Carbon-Coated ZnS with Sulfur-Vacancy Defect for Enhanced Photocatalytic Activity in the Visible Light Region. Nanomaterials 2019, 9, 1657. [CrossRef]

13. Shekofteh-Gohari, M.; Habibi-Yangjeh, A.; Abitorabi, M.; Rouhi, A. Magnetically separable nanocomposites based on $\mathrm{ZnO}$ and their applications in photocatalytic processes: A review. Crit. Rev. Environ. Sci. Technol. 2018, 48, 806-857. [CrossRef]

14. Liu, Y.; Zhang, M.Y.; Li, L.; Zhang, X.T. In situ ion exchange synthesis of the $\mathrm{Bi}_{4} \mathrm{Ti}_{3} \mathrm{O}_{12} / \mathrm{Bi}_{2} \mathrm{~S}_{3}$ heterostructure with enhanced photocatalytic activity. Catal. Commun. 2015, 60, 23. [CrossRef]

15. Shen, G.D.; Pu, Y.P.; Sun, R.J.; Shi, Y.; Cui, Y.F.; Jing, P.P. Enhanced visible light photocatalytic performance of a novel heterostructured $\mathrm{Bi}_{4} \mathrm{Ti}_{3} \mathrm{O}_{12} / \mathrm{BiOBr}$ photocatalyst. New J. Chem. 2019, 43, 1. [CrossRef]

16. Zheng, C.X.; Yang, H.; Cui, Z.; Zhang, H.M.; Wang, X.X. A novel $\mathrm{Bi}_{4} \mathrm{Ti}_{3} \mathrm{O}_{12} / \mathrm{Ag}_{3} \mathrm{PO}_{4}$ heterojunction photocatalyst with enhanced photocatalytic performance. Nanoscale Res. Lett. 2017, 12, 608. [CrossRef]

17. Liu, Y.; Wang, Z.; Fan, W.; Geng, Z.; Feng, L. Enhancement of the photocatalytic performance of Ni-loaded $\mathrm{TiO}_{2}$ photocatalyst under sunlight. Ceram. Int. 2014, 40, 3887-3893. [CrossRef] 
18. Zhang, F.; Liu, W.; Liu, Y.; Wang, J.; Ji, G. Fabrication and enhanced photocatalytic properties of $\mathrm{Pt}_{\mathrm{SSiO}} @ \mathrm{TiO}_{2}$ composites by surface plasma resonance from Pt nanoparticles. J. Nanopart. Res. 2015, 17, 62. [CrossRef]

19. Fujishima, A.; Rao, T.N.; Tryk, D.A. Titanium dioxide photocatalysis. J. Photochem. Photobiol. C Photochem. Rev. 2000, 1, 1-21. [CrossRef]

20. Khan, M.R.; Chuan, T.W.; Yousuf, A.; Chowdhury, N.K.; Cheng, C.K. Schottky barrier and surface plasmonic resonance phenomena towards the photocatalytic reaction: Study of their mechanisms to enhance photocatalytic activity. Catal. Sci. Technol. 2015, 5, 2522-2531. [CrossRef]

21. Wang, W.; Lai, M.; Fang, J.J.; Lu, C.H. Au and Pt selectively deposited on $\{001\}$-faceted $\mathrm{TiO}_{2}$ toward SPR enhanced photocatalytic $\mathrm{Cr}(\mathrm{VI})$ reduction: The influence of excitation wavelength. Appl. Surf. Sci. 2018, 439, 430-438. [CrossRef]

22. Chen, D.; Chen, Q.; Ge, L.; Yin, L.; Fan, B.; Wang, H.; Lu, H.; Xu, H.; Zhang, R.; Shao, G. Synthesis and Ag-loading-density-dependent photocatalytic activity of $\mathrm{Ag}_{\mathrm{T}} \mathrm{TiO}_{2}$ hybrid nanocrystals. Appl. Surf. Sci. 2013, 284, 921-929. [CrossRef]

23. Tian, L.; Li, J.; Liang, F.; Wang, J.; Li, S.; Zhang, H.; Zhang, S. Molten salt synthesis of tetragonal carbon nitride hollow tubes and their application for removal of pollutants from wastewater. Appl. Catal. B Environ. 2018, 225, 307-313. [CrossRef]

24. Li, J.Y.; Tian, L.; Liang, F.; Wang, J.K.; Han, L.; Zhang, J.; Ge, S.T.; Dong, L.H.; Zhang, H.J.; Zhang, S.W. Molten salt synthesis of hierarchical porous $\mathrm{N}$-doped carbon submicrospheres for multifunctional applications: High performance supercapacitor, dye removal and $\mathrm{CO}_{2}$ capture. Carbon 2019, 141, 739. [CrossRef]

25. Tian, L.; Li, J.; Liang, F.; Chang, S.; Zhang, H.; Zhang, M.; Zhang, S. Facile molten salt synthesis of atomically thin boron nitride nanosheets and their co-catalytic effect on the performance of carbon nitride photocatalyst. J. Colloid Interface Sci. 2019, 536, 664-672. [CrossRef]

26. Huang, Z.; Liu, J.; Huang, L.; Tian, L.; Wang, S.; Zhang, G.; Li, J.; Liang, F.; Zhang, H.; Jia, Q.; et al. One-step synthesis of dandelion-like lanthanum titanate nanostructures for enhanced photocatalytic performance. NPG Asia Mater. 2020, 12, 1-12. [CrossRef]

27. Huang, Z.; Duan, H.; Liu, J.; Zhang, H. Preparation of lanthanum cerate powders via a simple molten salt route. Ceram. Int. 2016, 42, 10482-10486. [CrossRef]

28. Sun, Y.; Zhao, Y.-F.; Sun, H.; Jia, F.-C.; Kumar, P.; Liu, B. Synthesis and room-temperature $\mathrm{H}_{2} \mathrm{~S}$ sensing of Pt nanoparticle-functionalized $\mathrm{SnO}_{2}$ mesoporous nanoflowers. J. Alloys Compd. 2020, 842, 155813. [CrossRef]

29. Lin, C.; Ma, C.Q.; Yi, F.T.; Zhang, H.N.; Qian, Y.X.; Zhang, K.F. Ag NPs modified plasmonic Z-scheme photocatalyst $\mathrm{Bi}_{4} \mathrm{Ti}_{3} \mathrm{O}_{12} / \mathrm{Ag} / \mathrm{Ag}_{3} \mathrm{PO}_{4}$ with improved performance for pollutants removal under visible light irradiation. Ceram. Int. 2020, 46, 14650-14661. [CrossRef]

30. Zhao, X.; Yang, H.; Li, S.; Cui, Z.; Zhang, C. Synthesis and theoretical study of large-sized $\mathrm{Bi}_{4} \mathrm{Ti}_{3} \mathrm{O}_{12}$ square nanosheets with high photocatalytic activity. Mater. Res. Bull. 2018, 107, 180-188. [CrossRef]

31. Pooladi, M.; Shokrollahi, H.; Lavasani, S.; Yang, H. Investigation of the structural, magnetic and dielectric properties of $\mathrm{Mn}$-doped $\mathrm{Bi}_{2} \mathrm{Fe}_{4} \mathrm{O}_{9}$ produced by reverse chemical co-precipitation. Mater. Chem. Phys. 2019, 229, 39-48. [CrossRef]

32. Du, C.; Li, D.H.; He, Q.Y.; Liu, J.M.; Li, W.; He, G.N.; Wang, Y.Z. Design and simple synthesis of composite $\mathrm{Bi}_{12} \mathrm{TiO}_{20} / \mathrm{Bi}_{4} \mathrm{Ti}_{3} \mathrm{O}_{12}$ with a good photocatalytic quantum efficiency and high production of photo-generated hydroxyl radicals. Phys. Chem. Chem. Phys. Pccp. 2016, 18, 26530. [CrossRef]

33. Li, Z.; Chen, M.; Hu, H.; Zhang, Q.; Tao, D. Mechanochemical synthesis of novel Pt modified ZnAl-LDH for effective ciprofloxacin photodegradation. J. Solid State Chem. 2020, 290, 121594. [CrossRef]

34. Zhao, X.; Yang, H.; Cui, Z.; Yi, Z.; Yu, H. Synergistically enhanced photocatalytic performance of $\mathrm{Bi}_{4} \mathrm{Ti}_{3} \mathrm{O}_{12}$ nanosheets by Au and Ag nanoparticles. J. Mater. Sci. Mater. Electron. 2019, 30, 13785-13796. [CrossRef]

35. Ganesh, R.S.; Sharma, S.K.; Abinnas, N.; Durgadevi, E.; Raji, P.; Muthamizhchelvan, C.; Ponnusamy, S.; Hayakawa, Y.; Kim, D.Y. Fabrication of the flexible nanogenerator from BTO nanopowders on graphene coated PMMA substrates by sol-gel method. Mater. Chem. Phys. 2017, 192, 274-281. [CrossRef]

36. Lin, X.; Guan, Q.F.; Liu, T.T.; Zhang, Y.; Zou, C.J. Controllable synthesis and photocatalytic activity of $\mathrm{Bi}_{4} \mathrm{Ti}_{3} \mathrm{O}_{12}$ particles with different morphologies. Acta Phys. Chim. Sin. 2013, 29, 411-417.

37. Liu, H.; Wu, R.; Tian, L.; Kong, Y.; Sun, Y. Synergetic photocatalytic effect between 1 T@2H-MoS 2 and plasmon resonance induced by Ag quantum dots. Nanotechnology 2018, 29, 285402. [CrossRef]

38. Zhang, X.; Wang, Y.; Hou, F.; Li, H.; Yang, Y.; Zhang, X.; Yang, Y.; Wang, Y. Effects of Ag loading on structural and photocatalytic properties of flower-like ZnO microspheres. Appl. Surf. Sci. 2017, 391, 476-483. [CrossRef] 
39. Sun, K.; Shen, J.; Liu, Q.; Tang, H.; Zhang, M.; Zulfiqar, S.; Lei, C. Synergistic effect of Co(II)-hole and Pt-electron cocatalysts for enhanced photocatalytic hydrogen evolution performance of P-doped g- $\mathrm{C}_{3} \mathrm{~N}_{4}$. Chin. J. Catal. 2020, 41, 72-81. [CrossRef]

40. Liu, J.; Li, Y.; Zhou, X.; Jiang, H.; Yang, H.G.; Li, C. Positively charged Pt-based cocatalysts: An orientation for achieving efficient photocatalytic water splitting. J. Mater. Chem. A 2020, 8, 17-26. [CrossRef]

41. Lin, D.; Gao, M.; You, L. Fabrication of novel $\mathrm{Ag} / \mathrm{AgVO} / 3 \mathrm{WO}_{3}$ homojunction/heterojunction nanomaterials with highly enhanced photocatalytic activity-Investigation on type plus Z-scheme mechanism. J. Alloys Compd. 2020, 846, 156274. [CrossRef]

42. Shen, X.; Yang, J.; Zheng, T.; Wang, Q.; Zhuang, H.; Zheng, R.; Shan, S.; Li, S. Plasmonic p-n heterojunction of $\mathrm{Ag} / \mathrm{Ag}_{2} \mathrm{~S} / \mathrm{Ag}_{2} \mathrm{MoO}_{4}$ with enhanced Vis-NIR photocatalytic activity for purifying wastewater. Sep. Purif. Technol. 2020, 251, 117347. [CrossRef]

43. Chang, M.J.; Cui, W.N.; Liu, J.; Wang, K.; Luo, Z.M. Construction of novel $\mathrm{TiO}_{2} / \mathrm{Bi}_{4} \mathrm{Ti}_{3} \mathrm{O}_{12} / \mathrm{MoS}_{2}$ core/shell nanofibers for enhanced visible light photocatalysis. J. Mater. Sci. Technol. 2020, 36, 97-105. [CrossRef]

44. Liu, Y.; Zhu, G.; Gao, J.; Hojamberdiev, M.; Zhu, R.; Wei, X.; Guo, Q.; Liu, P. Enhanced photocatalytic activity of $\mathrm{Bi}_{4} \mathrm{Ti}_{3} \mathrm{O}_{12}$ nanosheets by $\mathrm{Fe}^{3+}$-doping and the addition of Au nanoparticles: Photodegradation of Phenol and bisphenol A. Appl. Catal. B Environ. 2017, 200, 72-82. [CrossRef]

45. Chen, Z.; Jiang, X.; Zhu, C.; Shi, C. Chromium-modified $\mathrm{Bi}_{4} \mathrm{Ti}_{3} \mathrm{O}_{12}$ photocatalyst: Application for hydrogen evolution and pollutant degradation. Appl. Catal. B Environ. 2016, 199, 241-251. [CrossRef]

46. Zhao, X.; Yang, H.; Cui, Z.; Li, R.; Feng, W. Enhanced photocatalytic performance of $\mathrm{Ag}-\mathrm{Bi}_{4} \mathrm{Ti}_{3} \mathrm{O}_{12}$ nanocomposites prepared by a photocatalytic reduction method. Mater. Technol. 2017, 32, 870-880. [CrossRef]

47. Chen, Z.W.; Jiang, H.; Jin, W.L.; Shi, C.K. Enhanced photocatalytic performance over $\mathrm{Bi}_{4} \mathrm{Ti}_{3} \mathrm{O}_{12}$ nanosheets with controllable size and exposed $\{001\}$ facets for Rhodamine B degradation. Appl. Catal. B 2016, 180, 698. [CrossRef]

48. Dutta, D.P.; Tyagi, A. Facile sonochemical synthesis of Ag modified $\mathrm{Bi}_{4} \mathrm{Ti}_{3} \mathrm{O}_{12}$ nanoparticles with enhanced photocatalytic activity under visible light. Mater. Res. Bull. 2016, 74, 397-407. [CrossRef]

49. Guo, Y.; Li, J.H.; Gao, Z.Q.; Zhu, X.; Liu, Y.; Wei, Z.B.; Zhao, W.; Sun, C. A simple and effective method for fabricating novel p-n heterojunction photocatalyst $\mathrm{g}-\mathrm{C}_{3} \mathrm{~N}_{4} / \mathrm{Bi}_{4} \mathrm{Ti}_{3} \mathrm{O}_{12}$ and its photocatalytic performances. Appl. Catal. B 2016, 192, 57. [CrossRef]

50. Kamat, P.V. Meeting the Clean Energy Demand: Nanostructure Architectures for Solar Energy Conversion. J. Phys. Chem. C 2007, 111, 2834-2860. [CrossRef]

51. Zhu, J.; Zhou, Y.; Wu, W.; Deng, Y.; Xiang, Y. A Novel Rose-Like CuS/Bi ${ }_{2} \mathrm{WO}_{6}$ Composite for Rhodamine B Degradation. ChemistrySelect 2019, 4, 11853-11861. [CrossRef]

52. Herrmann, J.-M.; Tahiri, H.; Ait-Ichou, Y.; Lassaletta, G.; González-Elipe, A.R.; Fernández, A. Characterization and photocatalytic activity in aqueous medium of $\mathrm{TiO}_{2}$ and $\mathrm{Ag}-\mathrm{TiO}_{2}$ coatings on quartz. Appl. Catal. B Environ. 1997, 13, 219-228. [CrossRef]

53. Low, J.; Qiu, S.; Xu, D.; Jiang, C.; Cheng, B. Direct evidence and enhancement of surface plasmon resonance effect on Ag-loaded $\mathrm{TiO}_{2}$ nanotube arrays for photocatalytic $\mathrm{CO}_{2}$ reduction. Appl. Surf. Sci. 2018, 434, 423-432. [CrossRef]

54. Yan, T.; Tian, J.; Guan, W.; Qiao, Z.; Li, W.; You, J.; Huang, B. Ultra-low loading of $\mathrm{Ag}_{3} \mathrm{PO}_{4}$ on hierarchical $\mathrm{In}_{2} \mathrm{~S}_{3}$ microspheres to improve the photocatalytic performance: The cocatalytic effect of $\mathrm{Ag}$ and $\mathrm{Ag}_{3} \mathrm{PO}_{4}$. Appl. Catal. B Environ. 2017, 202, 84-94. [CrossRef]

55. Gao, J.; Ren, X.; Chen, D.; Tang, F.; Ren, J. Bimetallic Ag-Pt hollow nanoparticles: Synthesis and tunable surface plasmon resonance. Scr. Mater. 2007, 57, 687-690. [CrossRef]

Publisher's Note: MDPI stays neutral with regard to jurisdictional claims in published maps and institutional affiliations.

(C) 2020 by the authors. Licensee MDPI, Basel, Switzerland. This article is an open access article distributed under the terms and conditions of the Creative Commons Attribution (CC BY) license (http://creativecommons.org/licenses/by/4.0/). 